Article

\title{
Arene Ruthenium Metalla-Assemblies with Anthracene Moieties for PDT Applications
}

\author{
Marie Gaschard, Farzaneh Nehzat, Thomas Cheminel and Bruno Therrien * \\ Institute of Chemistry, University of Neuchâtel, Avenue de Bellevaux 51, CH-2000 Neuchâtel, Switzerland; \\ marie.gaschard@unine.ch (M.G.); salmanehzat@gmail.com (F.N.); cheminelt@gmail.com (T.C.) \\ * Correspondence: bruno.therrien@unine.ch; Tel.: +41-32-718-2499
}

Received: 16 July 2018; Accepted: 6 September 2018; Published: 12 September 2018

check for updates

\begin{abstract}
The synthesis and characterization of three metalla-rectangles of the general formula $\left[\mathrm{Ru}_{4}\left(\eta^{6}-p \text {-cymene }\right)_{4}\left(\mu_{4} \text {-clip }\right)_{2}\left(\mu_{2}-\mathbf{L}_{\text {anthr }}\right)_{2}\right]\left[\mathrm{CF}_{3} \mathrm{SO}_{3}\right]_{4}$ ( $\mathbf{L}_{\text {anthr }}: 9,10$-bis(3,3'-ethynylpyridyl) anthracene; clip = oxa: oxalato; dobq: 2,5-dioxido-1,4-benzoquinonato; donq: 5,8-dioxido-1, 4-naphthoquinonato) are presented. The molecular structure of the metalla-rectangle $\left[\mathrm{Ru}_{4}\left(\eta^{6}-p \text {-cymene }\right)_{4}\left(\mu_{4} \text {-oxa }\right)_{2}\left(\mu_{2}-\mathrm{L}_{\text {anthr }}\right)_{2}\right]^{4+}$ has been confirmed by the single-crystal X-ray structure analysis of $\left[\mathrm{Ru}_{4}\left(\eta^{6}-p \text {-cymene }\right)_{4}\left(\mu_{4} \text {-oxa }\right)_{2}\left(\mu_{2}-\mathbf{L}_{\mathbf{a n t h r}}\right)_{2}\right]\left[\mathrm{CF}_{3} \mathrm{SO}_{3}\right]_{4} \cdot 4$ acetone $\left(\mathbf{A}_{2} \cdot 4\right.$ acetone $)$, thus showing the anthracene moieties to be available for reaction with oxygen. While the formation of the endoperoxide form of $\mathbf{L}_{\text {anthr }}$ was observed in solution upon white light irradiation, the same reaction does not occur when $\mathbf{L}_{\mathbf{a n t h r}}$ is part of the metalla-assemblies.
\end{abstract}

Keywords: photodynamic therapy; singlet oxygen; anthracene; arene ruthenium; metalla-assemblies

\section{Introduction}

Nowadays, one of the challenges in treating cancers is increasing the drug efficacy while limiting or even annihilating side effects. Photodynamic therapy (PDT) can possibly achieve these goals [1,2]. Although still emerging and under development, this method is already used in the clinic or under clinical trials for skin disorders [3-5], infections [6,7], superficial cancers [3,8-10] and for deeper cancers [3,11-14] (see Table 1). PDT involves three main elements which are individually harmless: a light-absorbing molecule called photosensitizer (PS), oxygen and light. [15] For medical treatment, the PS is administered either systemically or topically and often intravenously. After a period of systemic distribution, the PS accumulates in the tumor, thanks to both selective accumulation and selective retention [16]. Finally, the tumor is irradiated by light, which activates the PS (Figure 1, part A). At that point, the combination of the PDT elements becomes dangerous for the cells. The PS, at its singlet ground state, is excited and reaches an unstable singlet state $S_{1}{ }^{*}$. Then, the PS reemits this energy and undergoes an intersystem crossing process leading to a triplet state $\mathrm{T}_{1}$, which is lower in energy (i.e., a longer-living state) than $S_{1}$. The PS subsequently interacts with the biological environment through two kinds of photochemical reactions (Figure 1, part B) [17]. Both pathways (type I and type II) involve oxidative stress, mainly due to the formation of reactive oxygen species (ROS), and accordingly need oxygen to be effective [18]. 
Table 1. List of photosensitizers approved by the FDA (Food and Drug Administration) or under clinical trials [14].

\begin{tabular}{|c|c|c|c|}
\hline Photosensitizers & Approved & Trial & Cancer Types \\
\hline $\begin{array}{l}\text { Porfimer sodium (hematoporphyrin, } \\
\text { Photofrin) }\end{array}$ & Worldwide & - & $\begin{array}{l}\text { Lung, esophagus, bile duct, } \\
\text { bladder, brain, ovarian }\end{array}$ \\
\hline ALA (5-aminolevulinic acid, Levulan) & Worldwide & - & $\begin{array}{l}\text { Skin, bladder, brain, } \\
\text { esophagus }\end{array}$ \\
\hline ALA esters & Europe & - & Skin, bladder \\
\hline $\begin{array}{l}\text { Temoporfin ( } m \text {-tetrahydroxy } \\
\text { phenylchlorin, Foscan) }\end{array}$ & Europe & USA & $\begin{array}{l}\text { Head, neck, lung, brain, skin, } \\
\text { bile duct }\end{array}$ \\
\hline Verteporfin & Europe & UK & $\begin{array}{l}\text { Ophthalmic (age-related } \\
\text { macular degeneration), } \\
\text { pancreatic, skin }\end{array}$ \\
\hline $\begin{array}{l}\text { HPPH (2-(1-hexyloxyethyl)-2-devinyl } \\
\text { pyropheophorbide-a) }\end{array}$ & - & USA & Head, neck, esophagus, lung \\
\hline $\mathrm{SnEt}_{2}$ (tin ethyl etiopurpurin, Purlytin) & - & USA & Skin, breast \\
\hline $\begin{array}{c}\text { Talaporfin } \\
\text { (mono-(L)-aspartylchlorin-e6) }\end{array}$ & & USA & Liver, colon, brain \\
\hline $\begin{array}{c}\text { Ce6-PVP (chlorin } \\
\text { e6-polyvinypyrroidone, Fotolon), } \\
\text { Ce6 derivatives } \\
\text { (photodithazine, Radachlorin) }\end{array}$ & - & Belarus, Russia & $\begin{array}{l}\text { Nasopharyngeal, } \\
\text { sarcoma, brain }\end{array}$ \\
\hline Silicon phthalocyanine & - & USA & Cutaneous T-cell lymphoma \\
\hline $\begin{array}{c}\text { Padoporfin } \\
\text { (pallado-porphyrin, TOOKAD) }\end{array}$ & - & USA & Prostate \\
\hline Motexafin lutetium (Lutex) & - & USA & Breast \\
\hline
\end{tabular}

Part A

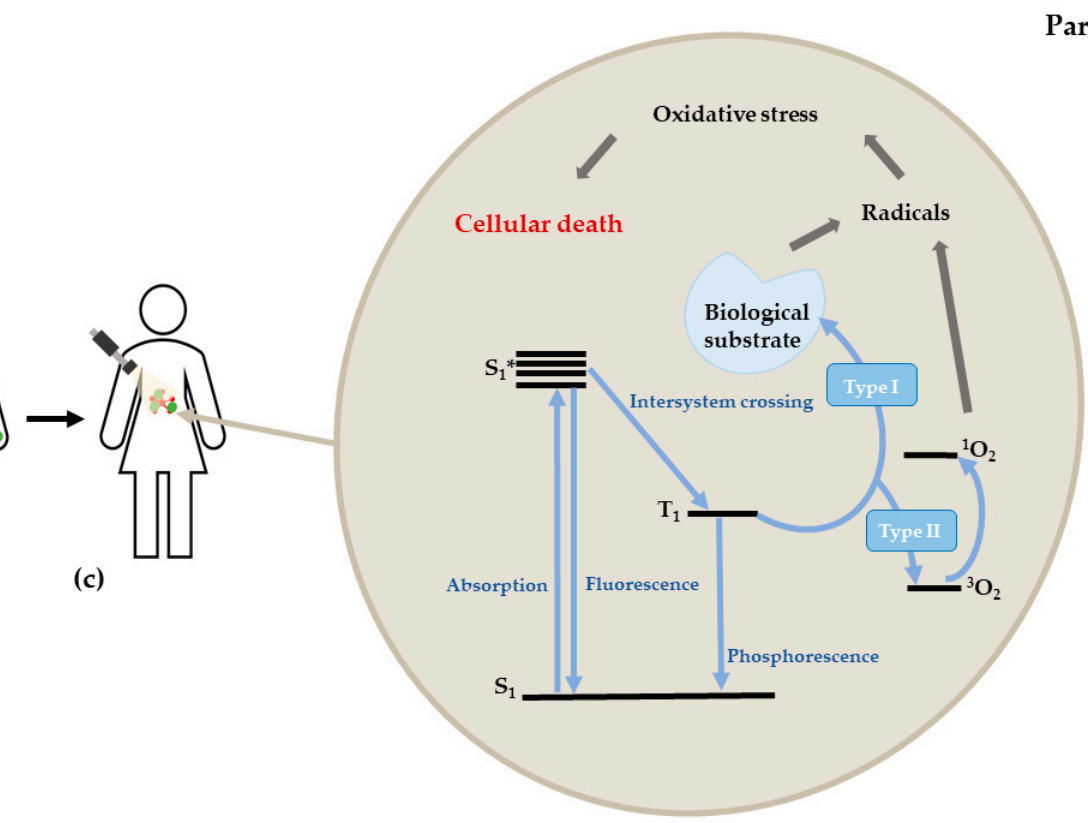

Figure 1. A-Standard PDT treatment: administration of PS (a) systemic PS distribution into the body; (b) PS accumulation in the tumor and irradiation (c); B-Jablonski diagram describing the PDT process. 
PDT is considered a promising treatment as it possesses several benefits in comparison to common cancer therapies. Traditionally, the advantages attributed to PDT are to be less invasive, with a short treatment time and a double selectivity (combination of PS and light); it can be applied several times at the same location (contrary to traditional radiations); and it has a lower overall cost (no surgery involved). Nevertheless, the PDT technique is still limited and its use in routine treatments remains restricted. Limitations are generally associated with a residual photosensitivity after PDT treatment, difficulty to treat metastases (because of limited laser focalization), the need of light at a specific wavelength to be able to reach deeper tumors and finally to an adequate tissue oxygenation $[2,14,19]$.

Unfortunately, hypoxia is a fundamental physiological feature in human solid cancers. This characteristic is absent in the healthy tissue and it corresponds to a low oxygen concentration in a determined cancerous region [20]. The first observation of this phenomenon was made by Thomlinson and Gray in the 1950s. They realized the importance of oxygen in cancerous tissues for obtaining a good efficiency of radiation treatments [21]. Later, they showed the existence of hypoxic and necrotic regions in cancerous areas, which are at $150 \mu \mathrm{m}$ from the irregular blood vessels. Consequently, they were able to deduce the effective diffusion distance of oxygen in cancer tissue [22]. In the 1990s, the concentration of oxygen in human tumors was precisely determined by Vaupel et al. Using the "Eppendorf" electrode: the oxygen amount is very heterogeneous, and the median values are lower than in healthy tissues [23]. Since then, researchers undoubtedly confirmed the negative impact of hypoxia on cancer treatments. Hypoxia generally drives to drug resistance and failure of the radioand chemotherapy [24,25], since cancerous cells exploit numerous mechanisms to survive. Here comes a non-exhaustive list of hypoxia consequences in a cancerous environment: an imperfect exposition of anti-cancerous drugs [26], a decrease of the DNA-breaking drugs toxicity [27,28], an upregulation of some genes [29,30], a selection of cells with genetic alterations carrying out the decrease or the suppression of apoptosis [31,32], a creation of genetic instability with an increased number of mutations [33], an adaptation of normal pathways to tumors for their survival [34,35], a dysfunction of RTK (receptor tyrosine kinase) and endocytosis [36], a tumor progression [37] and a restauration of the irradiation-damaged vasculature by vasculogenesis [38]. Thus, to apply the promising PDT treatment on human solid cancer, there is an indispensable need to overcome the problem of hypoxia, since oxygen remains a sine qua non condition for effectiveness.

Therefore, to carry oxygen to cancer cells, coordination chemistry can be a solution. In fact, several ruthenium-based complexes have been tested as photoactivated compounds and they appear to have good biological activity [39-53]. Moreover, we have demonstrated ten years ago the potential of arene ruthenium complexes in PDT [54-59], and recently we showed that the octonuclear metalla-cube $\left[\mathrm{Ru}_{8}\left(\eta^{6}-p \text {-cymene }\right)_{8}(\mathrm{tpvb})_{2}(\mathrm{donq})_{4}\right]^{8+}$ (tpvb: 1,2,3,4-tetrakis\{2-(4-pyridyl)vinyl\}benzene; donq: 5,8-dioxido-1,4-naphtoquinonato) can entrap porphin (a photosensitizer) into its cavity [60]. When inside the hydrophobic cavity of the cage, porphin is not reactive to light, and the overall assembly is relatively harmless to cells. After internalization, porphin is released within the cells, and, after an irradiation at an appropriate wavelength, the system shows an excellent phototoxicity. Therefore, we describe here a new strategy that consists of using arene ruthenium metalla-assemblies to transport one or two molecules of singlet oxygen. For that purpose, the literature gives several examples of oxygen carriers [61,62], but we have focused our attention to anthracene units [63-65]. Actually, Aubry and coworkers have described the ability of aromatic compounds to permit a reversible binding of oxygen [66]. Thus, the basic idea is to attach anthracene units on metalla-assemblies, either on the clips or on the linkers, and ultimately to be able to deliver ${ }^{1} \mathrm{O}_{2}$ and a PS to cells for PDT optimization.

In this conceptual paper, we have synthetized an anthracene-based linker, 9,10-bis(3,3'ethynylpyridyl) ( $\mathbf{L}_{\mathbf{a n t h r}}$ ), which form in combination with three arene ruthenium clips, $\left[\mathrm{Ru}_{2}\left(\eta^{6}-p \text {-cymene }\right)_{2}\left(\mu_{4} \mathrm{Oxa}\right)_{2} \mathrm{Cl}_{2}\right],\left[\mathrm{Ru}_{2}\left(\eta^{6}-p \text {-cymene }\right)_{2}\left(\mu_{4} \text {-dobq }\right)_{2} \mathrm{Cl}_{2}\right]$ and $\left[\mathrm{Ru}_{2}\left(\eta^{6}-p \text {-cymene }\right)_{2}\left(\mu_{4}-\mathrm{donq}\right)_{2} \mathrm{Cl}_{2}\right]$ (oxa: oxalato; dobq: 2,5-dioxido-1, 4-benzoquinonato; donq: 5,8-dioxido-1,4-naphthoquinonato), three metalla-rectangles $\left[\mathrm{Ru}_{4}\left(\eta^{6}-p \text {-cymene }\right)_{4}\left(\mu_{4} \text {-oxa }\right)_{2}\left(\mu_{2}-\mathbf{L}_{\text {anthr }}\right)_{2}\right]\left[\mathrm{CF}_{3} \mathrm{SO}_{3}\right]_{4}\left(\mathbf{A}_{\mathbf{1}}\right),\left[\mathrm{Ru}_{4}\left(\eta^{6}-p \text {-cymene }\right)_{4}\right.$ 
$\left.\left(\mu_{4} \text {-dobq }\right)_{2}\left(\mu_{2}-\mathbf{L}_{\text {anthr }}\right)_{2}\right]\left[\mathrm{CF}_{3} \mathrm{SO}_{3}\right]_{4}\left(\mathbf{A}_{2}\right)$, and $\left[\mathrm{Ru}_{4}\left(\eta^{6}-p \text {-cymene }\right)_{4}\left(\mu_{4} \text {-donq }\right)_{2}\left(\mu_{2}-\mathbf{L}_{\text {anthr }}\right)_{2}\right]\left[\mathrm{CF}_{3} \mathrm{SO}_{3}\right]_{4}\left(\mathbf{A}_{3}\right)$, respectively. Then, the potential of the linker $\mathbf{L}_{\mathbf{a n t h r}}$ and the arene ruthenium metalla-rectangles to act as oxygen carriers was evaluated by various spectroscopic methods.

\section{Results and Discussion}

The synthesis of the metalla-rectangles is straightforward. First, the bis-pyridyl linker, 9,10-bis(3,3'-ethynylpyridyl) ( $\mathbf{L}_{\mathbf{a n t h r}}$ ), is prepared according to a modified version of the previously published method [67]. It starts with a palladium-catalyzed Sonogashira reaction between 1 equivalent of 9,10-dibromoanthracene and 2.2 equivalents of 3-ethynylpyridine (63\% yield). Crystals of $\mathbf{L}_{\mathbf{a n t h r}}$ are obtained by the slow vapor diffusion of toluene into a solution of $\mathbf{L}_{\mathbf{a n t h r}}$ in dichloromethane at room temperature and they have permitted to confirm the molecular structure of $\mathbf{L}_{\mathbf{a n t h r}}$. The compound crystallized in the non-centrosymmetric space group $P 2_{1}$, a monoclinic crystal system. In the solid state, the anthracene unit is nearly planar with the root mean square deviation of the 12 carbon atoms of the plane being $0.024 \AA$. The angles between the anthracene plane and the pyridyl rings are $1.6^{\circ}$ and $2.9^{\circ}$, respectively. As illustrated in Figure 2, the occupancy of the nitrogen atoms of the pyridyl rings is poorly defined, showing the rotating flexibility around the ethynyl axes despite the conjugated aromatic system.

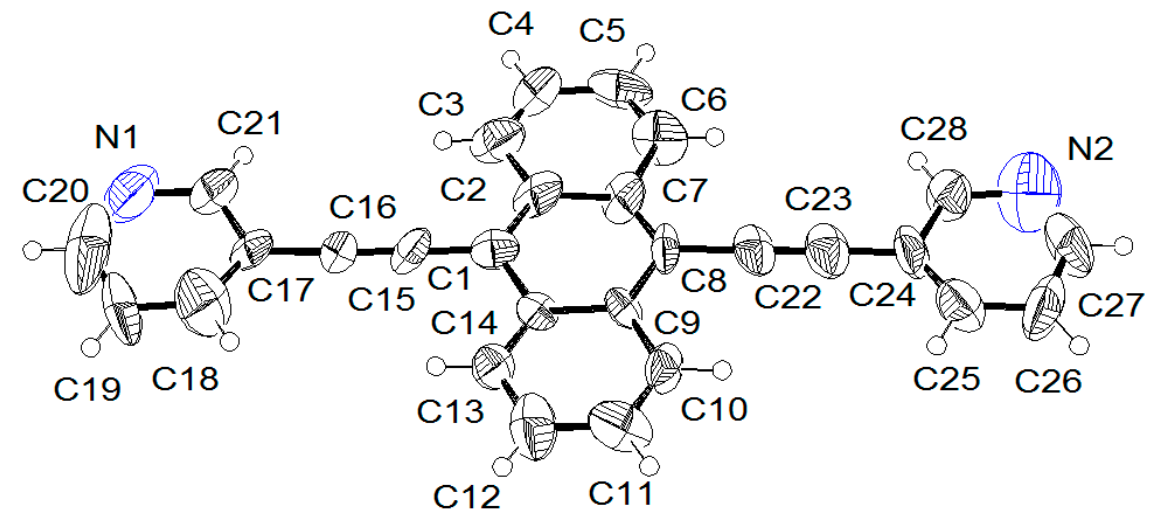

Figure 2. Ortep drawing of $\mathbf{L}_{\mathbf{a n t h r}}$ at $50 \%$ probability level ellipsoids.

Then, the dinuclear arene ruthenium clips were prepared according to published methods: $\quad\left[\mathrm{Ru}_{2}\left(\eta^{6}-p \text {-cymene }\right)_{2}\left(\mu_{4}\right.\right.$-oxa $\left.) \mathrm{Cl}_{2}\right] \quad[68], \quad\left[\mathrm{Ru}_{2}\left(\eta^{6}-p \text {-cymene }\right)_{2}\left(\mu_{4}\right.\right.$-dobq $\left.) \mathrm{Cl}_{2}\right] \quad$ [69] $\left[\mathrm{Ru}_{2}\left(\eta^{6}-p \text {-cymene }\right)_{2}\left(\mu_{4}\right.\right.$-donq) $\left.\mathrm{Cl}_{2}\right]$ [70]. These dinuclear complexes react with two equivalents of silver trifluoromethanesulfonate in dichloromethane to afford a reactive intermediate (not isolated), and after filtration of $\mathrm{AgCl}, 1$ equivalent of $\mathbf{L}_{\mathbf{a n t h r}}$ is added to obtain the corresponding metalla-rectangles (Scheme 1). The resulting cationic $p$-cymene metalla-assemblies are isolated as their trifluoromethanesulfonate $\left(\mathrm{CF}_{3} \mathrm{SO}_{3}{ }^{-}\right)$salts in good yields (between $68 \%$ and $82 \%$ ). The solubility of the metalla-rectangles depends on the nature of the dinuclear clip: $\mathbf{A}_{\mathbf{1}}$ is soluble in ethanol but not in dichloromethane, while $\mathbf{A}_{2}$ and $\mathbf{A}_{3}$ show the opposite, being soluble in dichloromethane but not in ethanol. Moreover, only $\mathbf{A}_{\mathbf{1}}$ is slightly soluble in water, but they are all soluble in acetone. These metalla-rectangles were fully characterized by various spectroscopic techniques (see the Supplementary Materials). 


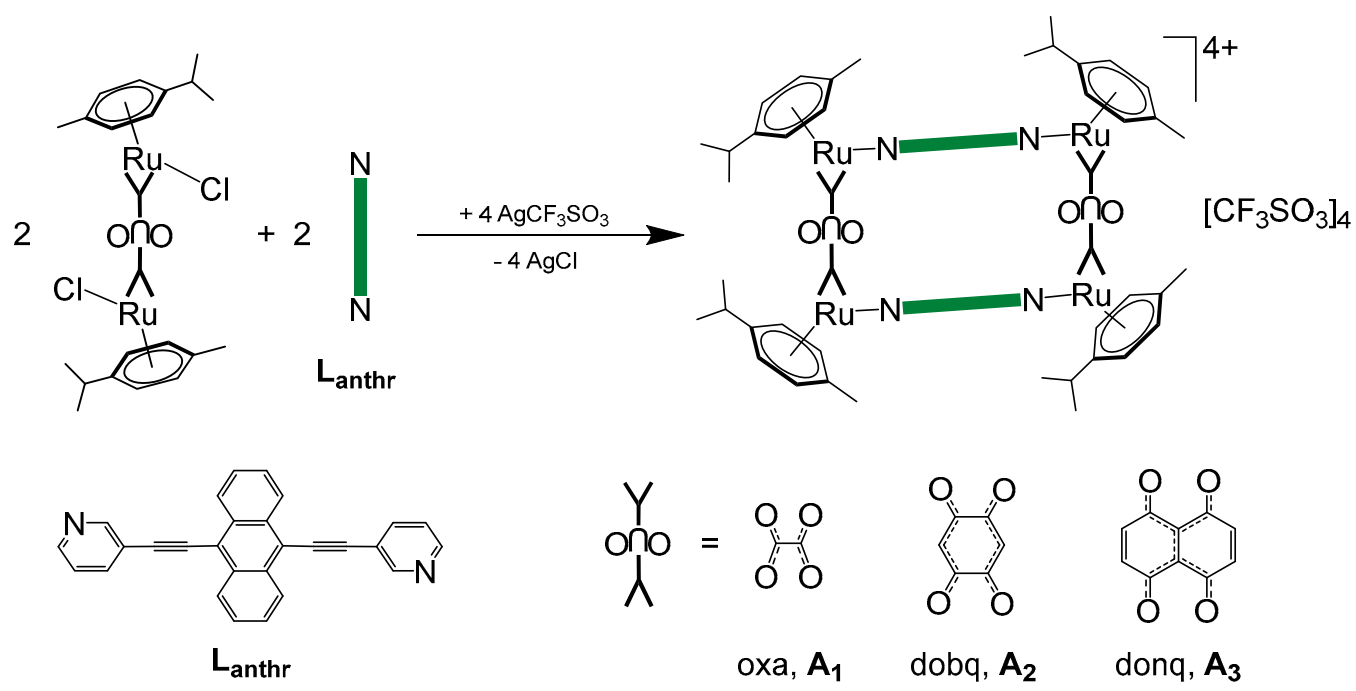

Scheme 1. Synthesis of $\mathbf{L}_{\mathbf{a n t h r}}$ and metalla-rectangles $\mathbf{A}_{\mathbf{1}}, \mathbf{A}_{\mathbf{2}}$ and $\mathbf{A}_{\mathbf{3}}$.

The formation of the metalla-rectangles $\mathbf{A}_{\mathbf{1}}, \mathbf{A}_{\mathbf{2}}$ and $\mathbf{A}_{\mathbf{3}}$ was first confirmed by electrospray ionization mass spectrometry (ESI-MS). All spectra show the typical pattern of arene ruthenium metalla-assemblies with trifluoromethanesulfonate as counterions: a monocationic peak corresponding to $\left[\mathrm{M}-\mathrm{CF}_{3} \mathrm{SO}_{3}{ }^{-}\right]^{+}$(respectively at $\mathrm{m} / z=2323.2$ and $\mathrm{m} / z=2423.0$; not observed for $\mathbf{A}_{3}$ ) and a dicationic peak for $\left[\mathrm{M}-2\left(\mathrm{CF}_{3} \mathrm{SO}_{3}{ }^{-}\right)\right]^{2+}$ (respectively at $\mathrm{m} / z=1088.9, \mathrm{~m} / \mathrm{z}=1139.2$ and $\mathrm{m} / \mathrm{z}=1188.1$ ). They also present a peak which corresponds to $\left[\mathrm{M}-2 \mathbf{L}_{\mathbf{a n t h r}}-2\left(\mathrm{CF}_{3} \mathrm{SO}_{3}{ }^{-}\right)\right]^{+}$at respectively $\mathrm{m} / \mathrm{z}=708.0, \mathrm{~m} / \mathrm{z}=759.3$ and $m / z=809.0$. The experimental results perfectly correlate with the calculated isotopic distributions of the different species.

The ${ }^{1} \mathrm{H}$ NMR spectra of $\mathbf{A}_{\mathbf{1}}, \mathbf{A}_{\mathbf{2}}$ and $\mathbf{A}_{\mathbf{3}}$ in acetone- $d_{6}$ present a chemical shift of the $\mathbf{L}_{\mathbf{a n t h r}}$ protons, as compared to the non-coordinated material (Figure 3). The pyridyl protons show a mixed behavior; those adjacent to the $\mathrm{Ru}-\mathrm{N}$ bond are shifted upfield, while the other two are shifted downfield. However, the protons of the anthracene units (marked by an orange triangle and a red dot) are strongly upfield shifted in all metalla-rectangles because of the shielding effect of the anthracene-anthracene parallel arrangement. In view of trapping singlet oxygen, these protons will be the most affected by the formation of the endoperoxide derivative.

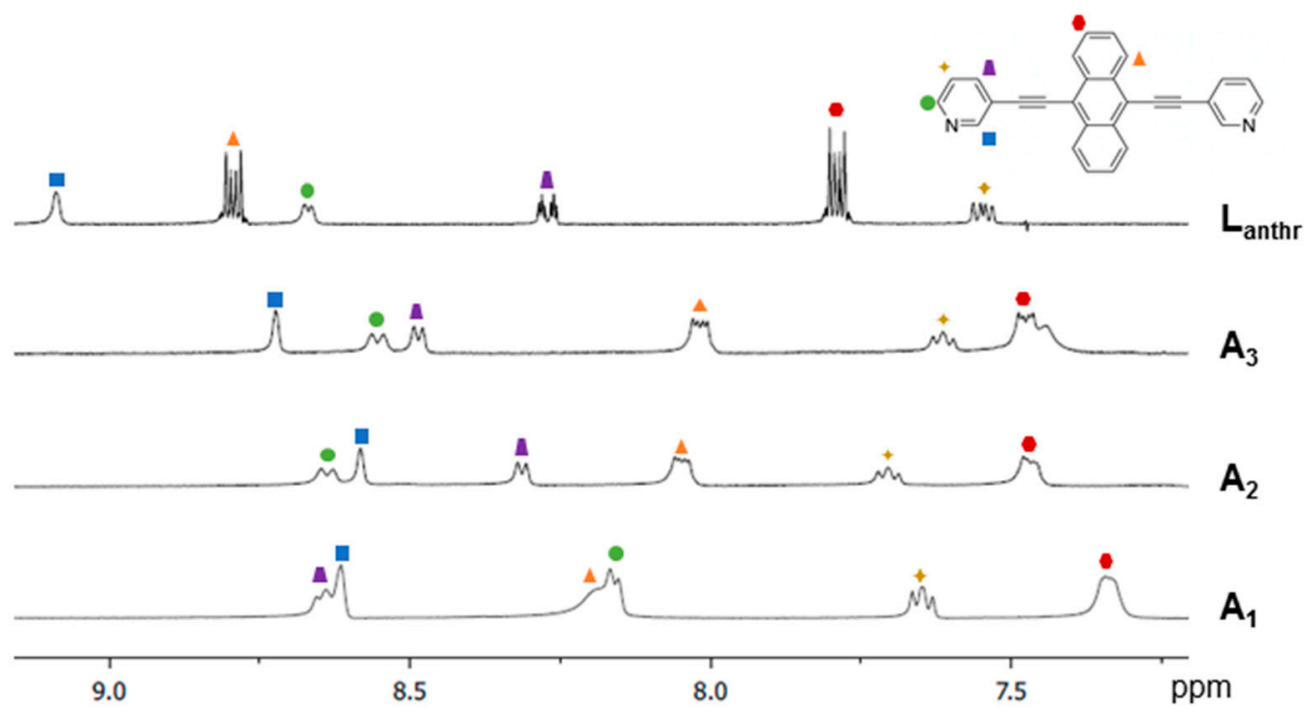

Figure 3. ${ }^{1} \mathrm{H}$ NMR spectra of the aromatic region of $\mathbf{L}_{\mathbf{a n t h r}}, \mathbf{A}_{\mathbf{3}}, \mathbf{A}_{\mathbf{2}}$ and $\mathbf{A}_{\mathbf{1}}$ (acetone- $d_{6}, 23{ }^{\circ} \mathrm{C}$ ). 
In addition, typical peak multiplicities and chemical shifts of the arene ruthenium units are observed in the ${ }^{1} \mathrm{H}$ NMR spectra of $\mathbf{A}_{\mathbf{1}}, \mathbf{A}_{\mathbf{2}}$ and $\mathbf{A}_{\mathbf{3}}$. The aryl protons of the $p$-cymene ligands are observed between $\sim 6.85$ and $\sim 6.35 \mathrm{ppm}$, the isopropyl protons at $\sim 1.40 \mathrm{ppm}$, the septuplet of the $-\mathrm{CH}$ from the isopropyl groups at $\sim 3.00 \mathrm{ppm}$ and the methyl groups at $\sim 2.30 \mathrm{ppm}$ (see the Experimental section). Interestingly, the spectrum of $\mathbf{A}_{\mathbf{1}}$ suggests the formation of two isomers due to the presence of broad signals in the aromatic region and due to additional splitting of some protons of the $p$-cymene ligands. On the other hand, the ${ }^{1} \mathrm{H}$ NMR spectra of $\mathbf{A}_{\mathbf{2}}$ and $\mathbf{A}_{\mathbf{3}}$ do not show this phenomenon and their overall signals are rather well-defined as compared to those of $\mathbf{A}_{\mathbf{1}}$. These elements support the presence of cis and trans isomers, in which the pyridyl units are pointing to the same or opposite sides of the metalla-rectangle: The free rotation of the pyridyl units being restricted upon formation of the metalla-rectangles. In fact, in the oxalato derivative $\mathbf{A}_{\mathbf{1}}$, the short distance between the ruthenium atoms within the dinuclear clip (5.4 $\AA$ ) forces the two $\mathbf{L}_{\text {anthr }}$ panels to be in close proximity [71]. Therefore, the chemical environment of the protons associated with the cis and trans isomers is more different. Accordingly, $\pi-\pi$ stacking interactions between the two $\mathbf{L}_{\mathbf{a n t h r}}$ units of the metalla-rectangles are stronger in $\mathbf{A}_{\mathbf{1}}$ than in $\mathbf{A}_{\mathbf{2}}$ and $\mathbf{A}_{\mathbf{3}}$, where the $\mathrm{Ru}-\mathrm{Ru}$ distances are estimated to be at 7.9 and $8.4 \AA$, respectively [71,72].

The diffusion coefficient $(D)$ of $\mathbf{A}_{\mathbf{1}}, \mathbf{A}_{\mathbf{2}}$ and $\mathbf{A}_{\mathbf{3}}$ was determined by Diffusion-Ordered Spectroscopy (DOSY) NMR experiments, recorded in acetone- $d_{6}$ at $23{ }^{\circ} \mathrm{C}$. The presence of a single diffusion line suggests, for each metalla-rectangle, the formation of one discrete species (isomers being undistinguishable). Interestingly, $\mathbf{A}_{\mathbf{1}}$ and $\mathbf{A}_{\mathbf{3}}$ have a similar value, at, respectively, $6.67 \times 10^{-10} \mathrm{~m}^{2} \cdot \mathrm{s}^{-1}$ and $6.80 \times 10^{-10} \mathrm{~m}^{2} \cdot \mathrm{s}^{-1}$, while $\mathbf{A}_{2}$ is slightly different $\left(6.04 \times 10^{-10} \mathrm{~m}^{2} \cdot \mathrm{s}^{-1}\right)$. Generally, the bigger the assembly is, the smaller its diffusion coefficient. Herein, the size of the metalla-rectangles is increasing from $\mathbf{A}_{\mathbf{1}}$ to $\mathbf{A}_{\mathbf{3}}$. However, the results are not consistent with their theoretical molecular size since $\mathbf{A}_{\mathbf{2}}$ has the smallest value of $D$. However, they might possess different arrangement in solution. Then, according to these $D$ values and by applying the Stockes-Einstein equation, the hydrodynamic radius $r_{\mathrm{H}}$ or the metalla-rectangles was calculated (viscosity of $0.31 \mathrm{mPa} \cdot \mathrm{s}$ for acetone and a temperature of $298 \mathrm{~K}$ ): the $r_{\mathrm{H}}$ values are $10.5 \AA$ for $\mathbf{A}_{\mathbf{1}}$ and $10.4 \AA$ for $\mathbf{A}_{\mathbf{3}}$, while for $\mathbf{A}_{\mathbf{2}}$ it is $11.7 \AA$. These values are consistent with the formation of the expected metalla-assemblies $[59,60,71-76]$.

Indeed, the molecular structure of $\mathbf{A}_{\mathbf{1}}$ was further confirmed by single-crystal X-ray structure analysis (Figure 4). Crystals were obtained by slow diffusion of a mixture of ether-benzene (99:1) into an acetone solution of the corresponding metalla-rectangle. The salt crystallizes in the triclinic space group $P$ - 1 . The asymmetric unit includes the tetra-cationic metalla-rectangle (trans isomer), four $\mathrm{CF}_{3} \mathrm{SO}_{3}{ }^{-}$anions, and four acetone molecules. The size of the rectangle defined by the four $\mathrm{Ru}-\mathrm{Ru}$ edges is $5.4 \times 17.7 \times 5.4 \times 17.9 \AA$, which correlates well with the $r_{\mathrm{H}}$ determined by the DOSY experiment.

As mentioned before, $\pi-\pi$ stacking interactions play an important role in the formation of these metalla-rectangles [77]. In the crystal structure of $\mathbf{A}_{\mathbf{1}} \cdot 4$ acetone, both anthracene groups are positioned in a "parallel fashion" that maximize $\pi-\pi$ stacking interactions. The distance between the two centroids of the anthracene moieties is only $3.8 \AA$. However, as compared to $\mathbf{L}_{\mathbf{a n t h r}}$, the pyridyl groups are far from co-planarity with the anthracene unit (Figure 4). Two pyridyl rings are observed at an angle of approximately $7^{\circ}$, while the two others are rotated by $34^{\circ}$, from the idealized plane of their anthracene group. This distortion is probably imposed by the arene ruthenium oxalato clips as well as by an optimization of the anthracene-anthracene $\pi-\pi$ interactions. 


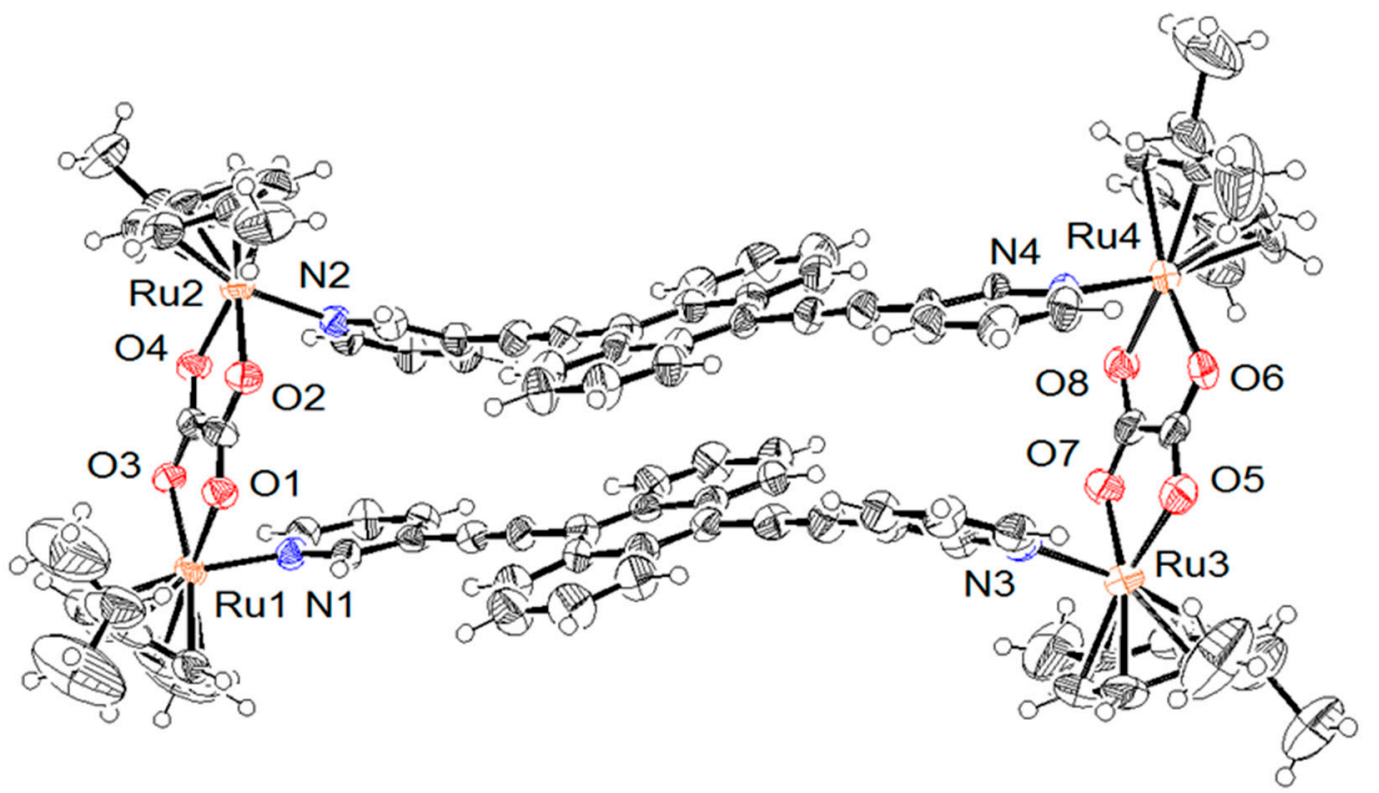

Figure 4. Molecular structure of $\mathbf{A}_{1} \cdot 4$ acetone at 50\% probability level ellipsoids. Trifluoromethanesulfonate and acetone molecules omitted for clarity.

The electronic absorption spectra have been measured at room temperature in dichloromethane for $\mathbf{L}_{\mathbf{a n t h r}}, \mathbf{A}_{\mathbf{2}}$ and $\mathbf{A}_{\mathbf{3}}$ and in ethanol for $\mathbf{A}_{\mathbf{1}}$ (Figure 5). The intense high energy band centered at $270 \mathrm{~nm}$ is assigned to ligand-localized or ligand $\pi \rightarrow \pi^{*}$ transition and the broad low-energy band corresponds to metal-to-ligand charge transfer (MLCT). Typical anthracene prints in the UV-visible spectra are observed around 400-500 $\mathrm{nm}$. These bands are different in the three metalla-assemblies. In fact, $\mathbf{A}_{\mathbf{1}}$ displays a quite similar pattern as $\mathbf{L}_{\mathbf{a} \text { thr }}$, while $\mathbf{A}_{\mathbf{2}}$ and $\mathbf{A}_{\mathbf{3}}$ show broader band and a bathochromic shift of the bands associated with the anthracene located between $\sim 400-550 \mathrm{~nm}$. Moreover, $\mathbf{A}_{\mathbf{2}}$ presents a wider band, from which it is not possible to distinguish in the visible region of the spectrum the two bands of the anthracene moiety.

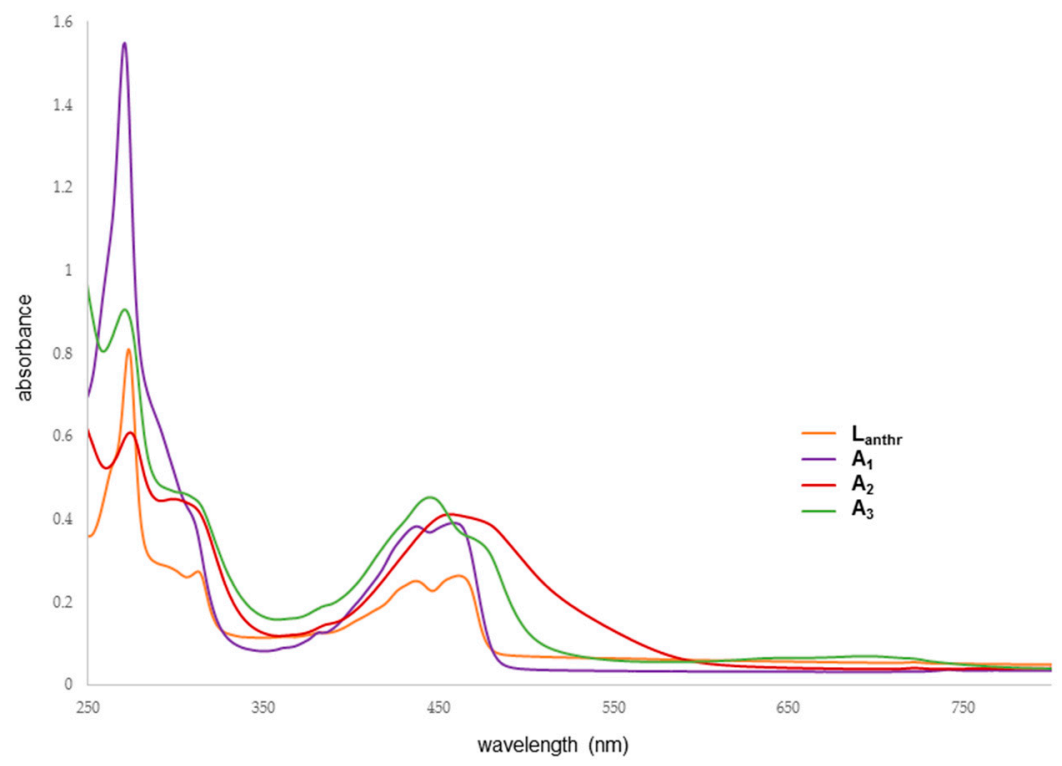

Figure 5. UV-visible spectra of $\mathbf{L}_{\mathbf{a n t h r}}, \mathbf{A}_{1}, \mathbf{A}_{\mathbf{2}}$ and $\mathbf{A}_{\mathbf{3}}$.

In order to evaluate the ability of the ligand and the metalla-rectangles to form endoperoxide derivatives, several experiments were carried out in solution (NMR, UV-visible and fluorescence). 
Comparisons were made between the results obtained under an inert-atmosphere to those obtained with an $\mathrm{O}_{2}$-saturated atmosphere, as well as before or after light irradiation.

First, UV-visible spectroscopy was used to visualize the trapping of singlet oxygen by the metalla-rectangles. When dealing with anthracene derivatives, a visible-light excitation can be employed to trap singlet oxygen, and upon oxygen addition to the anthracene moiety the intensity of the absorption bands decreases over time [78,79]. Therefore, solutions of all compounds were prepared at a concentration of $10^{-5} \mathrm{M}$ (EtOH for $\mathbf{A}_{1} ; \mathrm{CH}_{2} \mathrm{Cl}_{2}$ for $\mathbf{A}_{\mathbf{2}}$ and $\mathbf{A}_{3}$ ), and kept in the dark before starting the measurements. Then, multiple spectra were recorded: under nitrogen, after $15 \mathrm{~min}$ of oxygen bubbling into the solution, and also after one hour of visible light irradiation (cool white light, $\mathrm{Hg}$, $8 \mathrm{~W})$. However, in all cases, no spectroscopic changes were observed under these conditions.

We then turn our attention to fluorescence spectroscopy (Figure 6). Oxygen is known to be a common quencher of the fluorescence of aromatic compounds, since the formation of endoperoxide disrupts the electron delocalization of aromatic molecules [80-82]. Therefore, fluorescence spectroscopy was also used to study the behavior of the metalla-rectangles in the presence of $\mathrm{O}_{2}$. Each compound ( $5 \times 10^{-8} \mathrm{M}$ concentrations; EtOH for $\mathbf{A}_{\mathbf{1}} ; \mathrm{CH}_{2} \mathrm{Cl}_{2}$ for $\mathbf{A}_{\mathbf{2}}$ and $\left.\mathbf{A}_{3}\right)$ was irradiated at a specific wavelength, where the maximal absorbance was detected by the fluorimeter $\left(\mathbf{L}_{\mathbf{a n t h r}}, 271 \mathrm{~nm} ; \mathbf{A}_{\mathbf{1}}, 457 \mathrm{~nm} ; \mathbf{A}_{\mathbf{2}}, 273 \mathrm{~nm}\right.$; $\mathbf{A}_{3}, 459 \mathrm{~nm}$ ). At first sight, the spectra show different bands and intensities before and after placing the compounds under $\mathrm{O}_{2}$ (30 min of bubbling). In an inert atmosphere, $\mathbf{A}_{2}$ displays six bands: one at $\sim 270 \mathrm{~nm}$, two between 300 and $400 \mathrm{~nm}$, two between 450 and $520 \mathrm{~nm}$ and one at $\sim 550 \mathrm{~nm}$; while with $\mathrm{O}_{2}$, there are seven bands, one additional band at $\sim 620 \mathrm{~nm}$ (Figure 6). In the $\sim 270 \mathrm{~nm}$ and $\sim 550 \mathrm{~nm}$ regions, the intensity of the bands is decreasing with $\mathrm{O}_{2}$, whereas it is increasing in the other parts of the spectrum. Moreover, there is a slight hypsochromic shift of the bands located between 300 and $400 \mathrm{~nm}$.
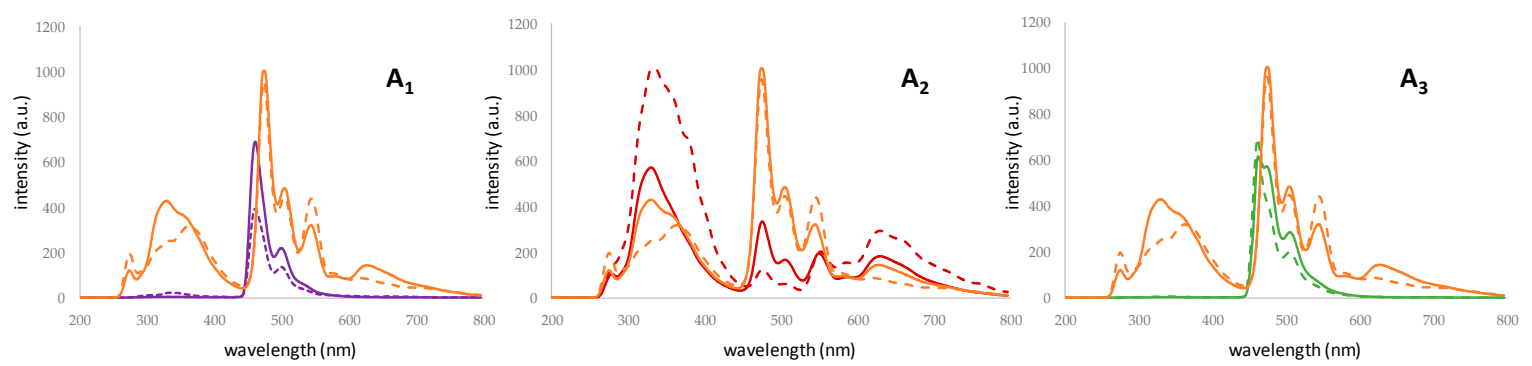

Figure 6. Fluorescence spectra of metalla-rectangles $\mathbf{A}_{\mathbf{1}}$ (purple), $\mathbf{A}_{\mathbf{2}}$ (red), $\mathbf{A}_{\mathbf{3}}$ (green) and $\mathbf{L}_{\mathbf{a n t h r}}$ (orange) at a concentration of $5 \times 10^{-8} \mathrm{M}$ (in $\mathrm{CH}_{2} \mathrm{Cl}_{2}$ or EtOH), under a $\mathrm{N}_{2}$ (dotted lines) or $\mathrm{O}_{2}$ atmosphere (solid line).

For $\mathbf{A}_{\mathbf{1}}$ and $\mathbf{A}_{\mathbf{3}}$ (Figure 6), no band before $450 \mathrm{~nm}$ is observed, and all their bands are hyperchromic. Only a very small decrease in the intensity of the band at $\sim 470 \mathrm{~nm}$ is observed for $\mathbf{A}_{3}$. In comparison with $\mathbf{L}_{\mathbf{a n t h r}}$, the behavior of $\mathbf{A}_{\mathbf{2}}$ follows an opposite trend: when the intensity is increasing for $\mathbf{L}_{\mathbf{a n t h r}}$, it is decreasing for $\mathbf{A}_{\mathbf{2}}$. The only different variation is the intensity of its bands: in the UV part and at the end of the visible domain, $\mathbf{A}_{\mathbf{2}}$ has a more intense fluorescence, and a less intense one between 450 and 550-570 nm. All together, these results show no evidence for an endoperoxide formation on the metalla-rectangles $\mathbf{A}_{\mathbf{1}}-\mathbf{A}_{\mathbf{3}}$. Therefore, we focused our attention to $\mathbf{L}_{\mathbf{a n t h r}}$ alone, in order to determine if the bis-pyridyl anthracene ligand interacts with $\mathrm{O}_{2}$.

A series of UV-visible spectra have been recorded (Figure 7), in which an air-opened solution of $\mathbf{L}_{\text {anthr }}$ was continuously irradiated under white light. After a week, the intensity of the bands associated with the anthracene moiety was significantly reduced, and the solution appeared to have reached an equilibrium. Two isosbestic points were observed, at $\sim 330 \mathrm{~nm}$ and $\sim 390 \mathrm{~nm}$, respectively. The formation of a new compound was confirmed by ${ }^{1} \mathrm{H}$ NMR spectroscopy, in which a new set of signals was observed. Two new doublet of doublets, slightly downfield shifted as compared to 
the anthracene protons of $\mathbf{L}_{\mathbf{a n t h r}}(8.7$ and $7.7 \mathrm{ppm})$, are observed at 8.8 and $7.9 \mathrm{ppm}$, respectively: thus suggesting the formation of the endoperoxide derivative.

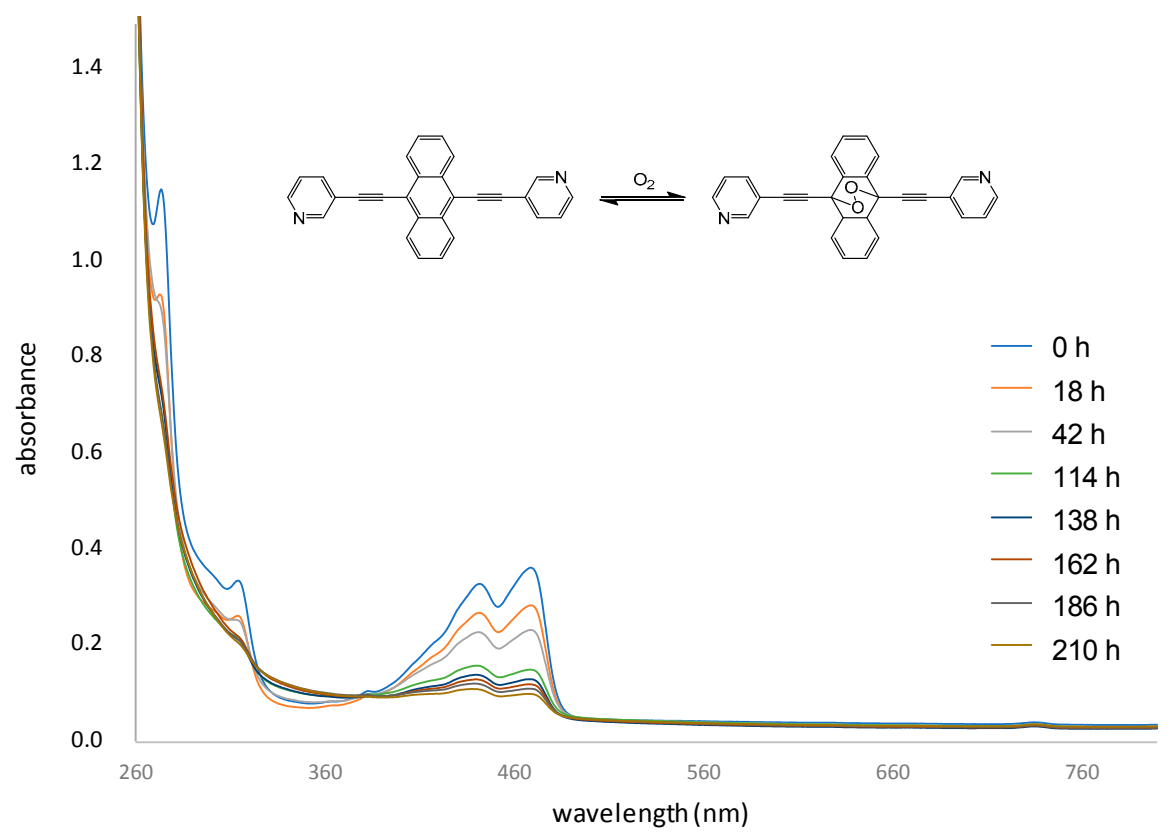

Figure 7. UV-visible spectra of $\mathbf{L}_{\mathbf{a n t h r}}$ upon white light irradiation ( $10^{-5} \mathrm{M}$ in DMSO).

\section{Experimental Section}

\subsection{Material and Methods}

All solvents were dried before use according to standard procedures and all reactions were performed under an inert atmosphere. The ruthenium precursors [ $\mathrm{Ru}_{2}\left(\eta^{6}-p \text {-cymene }\right)_{2}\left(\mu_{4}\right.$-oxa $\left.) \mathrm{Cl}_{2}\right]$ [68], $\left[\mathrm{Ru}_{2}\left(\eta^{6}-p \text {-cymene }\right)_{2}\left(\mu_{4}\right.\right.$-dobq $) \mathrm{Cl}_{2}$ ] [69] and $\left[\mathrm{Ru}_{2}\left(\eta^{6}-p \text {-cymene }\right)_{2}\left(\mu_{4}\right.\right.$-donq $\left.) \mathrm{Cl}_{2}\right]$ [70] were prepared according to published methods. All other reagents were commercially available (Sigma-Aldrich, Brunschwig, Basel, Switzerland) and used as received. NMR spectra were recorded with a Bruker Avance II 400 spectrometer (Karlsruhe, Germany). UV-vis absorption spectra were recorded with a PerkinElmer UV-vis spectrophotometer (Waltham, MA, USA). IR spectra were recorded with a Thermoscientific Nicolet iS5 spectrometer (Waltham, MA, USA). Electrospray ionization mass spectrometry (ESI-MS) spectra were obtained in positive mode with a LCQ Finnigan mass spectrometer (San Jose, CA, USA). Microanalyses were carried out by the Mikroelementaranalytisches Laboratorium, ETH Zurich, Switzerland. Fluorescence spectra were recorded on a PerkinElmer LS 50 B luminescence spectrophotometer (Waltham, MA, USA). Irradiation studies were performed using a Luzchem LZC-ORG photoreactor (Montreal, QC, Canada) equipped with the corresponding lamp (cool white lamp, $\mathrm{Hg}, 8 \mathrm{~W}$, Sylvania $\left.{ }^{\circledR} \mathrm{F} 8 \mathrm{~T} 5 / \mathrm{CW}\right)$.

\subsection{Synthesis and Characterization}

9,10-bis(3,3'-ethynylpyridyl)anthracene ( $\left.L_{\text {anthr }}\right)$ : In a Schlenk flask, a mixture of 9,10-dibromoanthracene (400 mg, $1.19 \mathrm{mmol}$ ) and 3-ethynylpyridine (270 mg, $2.62 \mathrm{mmol}$ ) was dissolved in a solution of toluene:trimethylamine $(1: 1,25 \mathrm{~mL})$ and let under a nitrogen atmosphere during $15 \mathrm{~min}$. Then, a mixture of palladium(II)acetate $(5 \mathrm{mg}, 0.024 \mathrm{mmol})$, copper(I)iodide $(6 \mathrm{mg}$, $0.030 \mathrm{mmol})$ and triphenylphosphine $(17 \mathrm{mg}, 0.065 \mathrm{mmol})$ was added to this solution. The reaction mixture was stirred at reflux for $24 \mathrm{~h}$. The solvent was removed under vacuum. The residue was dissolved in water and stirred for $2 \mathrm{~h}$ at RT, to eliminate the triethylammonium salt. The solid was filtered off and dried under vacuum. Recrystallization was done in toluene and the product was obtain 
as orange needles, which were dried under vacuum $(285 \mathrm{mg}, 63 \%) .{ }^{1} \mathrm{H} \mathrm{NMR}\left(\mathrm{CDCl}_{3}, 400 \mathrm{MHz}\right): \delta 9.02$ $\left(\mathrm{s}, 2 \mathrm{H}, \mathrm{CH}_{\mathrm{pyr}}\right), 8.66\left(\mathrm{~m}, 6 \mathrm{H}, \mathrm{CH}_{\mathrm{pyr}}\right.$ and $\left.\mathrm{CH}_{\text {anth }}\right), 8.06\left(\mathrm{~d}, J=7.6 \mathrm{~Hz}, 2 \mathrm{H}, \mathrm{CH}_{\mathrm{pyr}}\right), 7.69\left(\mathrm{dd}, 4 \mathrm{H}, \mathrm{CH}_{\text {anth }}\right)$, $7.42\left(\mathrm{~m}, 2 \mathrm{H}, \mathrm{CH}_{\text {pyr }}\right) .{ }^{13} \mathrm{C} \mathrm{NMR}\left(\mathrm{CDCl}_{3}, 400 \mathrm{MHz}\right): \delta 152.4\left(2 \mathrm{C}, \mathrm{CH}_{\text {pyr }}\right), 149.2\left(2 \mathrm{C}, \mathrm{CH}_{\text {pyr }}\right), 138.6(2 \mathrm{C}$, $\left.\mathrm{CH}_{\text {pyr }}\right), 132.3$ (4C, $\left.\mathrm{C}_{\text {anthr }}\right), 127.4$ (4C, $\left.\mathrm{CH}_{\text {anthr }}\right), 127.3$ (4C, $\left.\mathrm{CH}_{\text {anthr }}\right), 123.4\left(2 \mathrm{C}, \mathrm{CH}_{\text {pyr }}\right), 120.7\left(2 \mathrm{C}, \mathrm{C}_{\text {pyr }}\right)$, 118.4 (2C, $\left.C_{\text {anthr }}\right), 99.12$ (2C, $\left.C_{\text {ethynyl }}\right), 89.77$ (2C, $\left.C_{\text {ethynyl }}\right)$. IR ( $\left.\mathrm{cm}^{-1}\right): 3078$ (m; C-H aromatic), 2200 (w; C $\equiv \mathrm{C}), 1557$ and 1477 (m; C=C aromatic), 799, 763 and 697 (s, sharp; C-H aromatic). ESI-MS (+); $m / z=381.2[\mathrm{M}+\mathrm{H}]^{+}$. UV-vis $\left[5.0 \times 10^{-6}, \mathrm{CH}_{2} \mathrm{Cl}_{2} ; \lambda_{\max }, \mathrm{nm}\left(\varepsilon, \mathrm{M}^{-1} \cdot \mathrm{cm}^{-1}\right)\right]: 277\left(1.2 \times 10^{5}\right), 313(5.5 \times$ $\left.10^{4}\right), 437\left(5.0 \times 10^{4}\right), 462\left(5.3 \times 10^{4}\right), 722\left(1.1 \times 10^{4}\right)$. Anal. calc. for $\mathrm{C}_{28} \mathrm{H}_{16} \mathrm{~N}_{2}$ (380.46): C 88.38, $\mathrm{H} 4.25$, N 7.37; Found: C 88.26, H 4.14, N 7.26.

General procedure for the synthesis of metalla-rectangles $A_{1}, A_{2}$ and $A_{3}$ : $A$ mixture of metalla-clip (oxa: $200 \mathrm{mg}, 0.32 \mathrm{mmol}$; dobq: $200 \mathrm{mg}, 0.29 \mathrm{mmol}$; donq: $200 \mathrm{mg}, 0.27 \mathrm{mmol}$ ) and silver trifluoromethanesulfonate (2 eq.) was dissolved in dichloromethane and was stirred for $3 \mathrm{~h}$ at RT. The mixture was filtrated in order to eliminate silver chloride. The resulting solution was added to a dichloromethane solution of $\mathbf{L}_{\mathbf{a n t h r}}$ (1 eq.). Then, the mixture was refluxed overnight and consequently concentrated under vacuum. The concentrated solution was slowly poured into cold diethyl ether to induce precipitation. After filtration, the metalla-rectangles were filtered off and dried under vacuum.

$\left[\mathrm{Ru}_{4}\left(\eta^{6} \text {-p-cymene }\right)_{4}\left(\mu_{4} \text {-oxa }\right)_{2}\left(\mu_{2}-\mathrm{L}_{\text {anthr }}\right)_{2}\right]\left[\mathrm{CF}_{3} \mathrm{SO}_{3}\right]_{4}\left(\mathrm{~A}_{1}\right)$ : Yellow solid. Yield, $74 \%$. ${ }^{1} \mathrm{H} \mathrm{NMR}$ $\left(\left(\mathrm{CD}_{3}\right)_{2} \mathrm{CO}, 400 \mathrm{MHz}\right): \delta 8.64\left(\mathrm{~m}, 8 \mathrm{H}, \mathrm{CH}_{\text {pyr }}\right), 8.16\left(\mathrm{~m}, 12 \mathrm{H}, \mathrm{CH}_{\text {anthr }}\right), 7.65\left(\mathrm{t}, J=6.6 \mathrm{~Hz}, 4 \mathrm{H}, \mathrm{CH}_{\text {pyr }}\right)$, $7.34\left(\mathrm{~m}, 8 \mathrm{H}, \mathrm{CH}_{\text {anthr }}\right), 6.20\left(\mathrm{dd}, J=11.6 \mathrm{~Hz}, J=6.0 \mathrm{~Hz}, 8 \mathrm{H}, \mathrm{CH}_{\text {cym }}\right), 6.05\left(\mathrm{~m}, 8 \mathrm{H}, \mathrm{CH}_{\text {cym }}\right), 3.04$ (sept, $\left.J=6.6 \mathrm{~Hz}, 4 \mathrm{H}, \mathrm{CH}_{\text {cym }}\right), 2.35\left(\mathrm{~s}, 12 \mathrm{H}, \mathrm{CH}_{3 \text { cym }}\right), 1.45\left(\mathrm{~d}, J=6.8 \mathrm{~Hz}, 12 \mathrm{H}, \mathrm{CH}_{\text {cym }}\right), 1.43(\mathrm{~d}, J=6.8 \mathrm{~Hz}$, $\left.12 \mathrm{H}, \mathrm{CH}_{\text {cym }}\right) .{ }^{13} \mathrm{C}$ NMR $\left(\left(\mathrm{CD}_{3}\right)_{2} \mathrm{CO}, 400 \mathrm{MHz}\right): \delta 172.14\left(2 \mathrm{C}, \mathrm{C}_{\text {oxa }}\right), 172.03\left(2 \mathrm{C}, \mathrm{C}_{\text {oxa }}\right), 154.65\left(4 \mathrm{C}, \mathrm{C}_{\text {pyr }}\right)$, 152.54 (4C, $\left.C_{\text {pyr }}\right), 143.77$ (4C, $\left.C_{\text {pyr }}\right), 137.19$ (4C, $\left.C_{\text {anthr }}\right), 131.42$ (4C, $\left.C_{\text {anthr }}\right), 128.15$ (8C, $\left.C_{\text {anthr }}\right), 127.65$ (4C, $\left.C_{\text {pyr }}\right), 127.17$ (8C, $\left.C_{\text {anthr }}\right), 123.78$ (4C, C pyr $), 120.90$ (4C, C anthr $), 117.87$ (4C, C Otf $), 103.43$ (4C, C cym), $98.98\left(4 \mathrm{C}, \mathrm{C}_{\text {cym }}\right), 97.40\left(4 \mathrm{C}, \mathrm{C}_{\mathrm{C} \equiv \mathrm{C}}\right), 92.88\left(4 \mathrm{C}, \mathrm{C}_{\mathrm{C} \equiv \mathrm{C}}\right), 83.34\left(2 \mathrm{C}, \mathrm{C}_{\text {cym }}\right), 83.26\left(2 \mathrm{C}, \mathrm{C}_{\text {cym }}\right), 83.14(4 \mathrm{C}$, $\left.\mathrm{C}_{\text {cym }}\right), 82.85\left(2 \mathrm{C}, \mathrm{C}_{\text {cym }}\right), 82.79\left(2 \mathrm{C}, \mathrm{C}_{\text {cym }}\right), 82.30\left(2 \mathrm{C}, \mathrm{C}_{\text {cym }}\right), 82.28\left(2 \mathrm{C}, \mathrm{C}_{\text {cym }}\right), 31.96\left(4 \mathrm{C}, \mathrm{C}_{\text {cym }}\right), 22.69$ (4C,

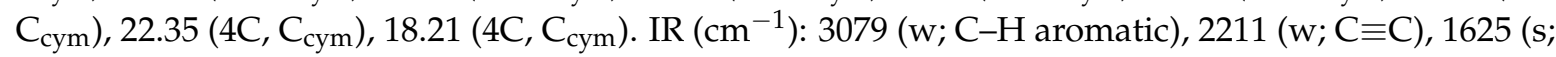
$\mathrm{C}=\mathrm{O}$ oxa), 1482 (m; C=C aromatic), 765 (m, sharp; $\mathrm{C}-\mathrm{H}$ aromatic), 636 (s; C-H aromatic). ESI-MS (+); $m / z=708.0\left[\mathrm{M}-2 \mathbf{L}_{\text {anthr }}-2 \mathrm{OTf}^{-}\right]^{+}, 1088.9\left[\mathrm{M}-2 \mathrm{OTf}^{-}\right]^{2+}, 2323.2\left[\mathrm{M}-\mathrm{OTf}^{-}\right]^{+}$. UV-vis $\left[5.0 \times 10^{-6}, \mathrm{EtOH}^{2}\right.$ $\left.\lambda_{\max }, \mathrm{nm}\left(\varepsilon, \mathrm{M}^{-1} \cdot \mathrm{cm}^{-1}\right)\right]: 271\left(3.1 \times 10^{5}\right), 312\left(7.5 \times 10^{4}\right), 437\left(7.6 \times 10^{4}\right), 459\left(7.8 \times 10^{4}\right), 742(7.3 \times$ $\left.10^{3}\right)$. D ((CD $\left.)_{2} \mathrm{CO}\right): 6.67 \times 10^{-10} \mathrm{~m}^{2} \cdot \mathrm{s}^{-1}$. Anal. calc. for $\mathrm{C}_{104} \mathrm{H}_{88} \mathrm{~F}_{12} \mathrm{~N}_{4} \mathrm{O}_{20} \mathrm{Ru}_{4} \mathrm{~S}_{4}(2474.48): \mathrm{C} 50.48, \mathrm{H}$ 3.59, N 2.27; Found: C 50.56, H 3.68, N 2.22.

$\left[\mathrm{Ru}_{4}\left(\eta^{6}-p \text {-cymene }\right)_{4}\left(\mu_{4}-\mathrm{dobq}\right)_{2}\left(\mu_{2}-\mathrm{L}_{\mathrm{anthr}}\right)_{2}\right]\left[\mathrm{CF}_{3} \mathrm{SO}_{3}\right]_{4}\left(\mathrm{~A}_{2}\right):$ Red solid. Yield, 68\%. ${ }^{1} \mathrm{H} \mathrm{NMR}$ $\left(\left(\mathrm{CD}_{3}\right)_{2} \mathrm{CO}, 400 \mathrm{MHz}\right): \delta 8.64\left(\mathrm{~d}, J=7.6 \mathrm{~Hz}, 4 \mathrm{H}, \mathrm{CH}_{\text {pyr }}\right), 8.58\left(\mathrm{~s}, 4 \mathrm{H}, \mathrm{CH}_{\text {pyr }}\right), 8.31(\mathrm{~d}, J=6.0 \mathrm{~Hz}, 4 \mathrm{H}$, $\left.\mathrm{CH}_{\text {pyr }}\right), 8.05\left(\mathrm{dd}, J=6.8 \mathrm{~Hz}, J=3.2 \mathrm{~Hz}, 8 \mathrm{H}, \mathrm{CH}_{\text {anthr }}\right), 7.70\left(\mathrm{t}, J=6.8 \mathrm{~Hz}, 4 \mathrm{H}, \mathrm{CH}_{\text {pyr }}\right), 7.47\left(\mathrm{~m}, 8 \mathrm{H}, \mathrm{CH}_{\text {anthr }}\right)$, $6.34\left(\mathrm{~d}, J=6.0 \mathrm{~Hz}, 8 \mathrm{H}, \mathrm{CH}_{\mathrm{cym}}\right), 6.11\left(\mathrm{~d}, J=6.0 \mathrm{~Hz}, 8 \mathrm{H}, \mathrm{CH}_{\mathrm{cym}}\right), 5.96\left(\mathrm{~s}, 4 \mathrm{H}, \mathrm{CH}_{\mathrm{dobq}}\right), 3.04(\mathrm{sept}, J=6.6$ $\left.\mathrm{Hz}, 4 \mathrm{H}, \mathrm{CH}_{\text {cym }}\right), 2.33$ (s, 12H, CH $\left.\mathrm{CH}_{3 \text { cym }}\right), 1.42$ (d, J = 6.8 Hz, 24H, $\left.\mathrm{CH}_{\text {cym }}\right) .{ }^{13} \mathrm{C} \mathrm{NMR}\left(\left(\mathrm{CD}_{3}\right)_{2} \mathrm{CO}, 400\right.$ MHz): $\delta 184.40$ (8C, $C_{\text {dobq }}$ ), 155.33 (4C, $\left.C_{\text {pyr }}\right), 153.20$ (4C, $\left.C_{\text {pyr }}\right), 142.77\left(4 \mathrm{C}, \mathrm{C}_{\text {pyr }}\right), 131.27$ (8C, $\left.C_{\text {anthr }}\right)$, 128.27 (8C, $\left.C_{\text {anthr }}\right), 127.32$ (4C, $\left.C_{\text {pyr }}\right), 127.06$ (8C, C anthr $), 123.96$ (1C, $\left.C_{\text {anthr }}\right), 123.30\left(1 \mathrm{C}, C_{\text {anthr }}\right), 120.76$ (4C, $\left.C_{\text {pyr }}\right), 117.69$ (2C, $\left.C_{\text {anthr }}\right), 104.84$ (4C, $\left.C_{\text {cym }}\right), 102.37$ (4C, $\left.C_{\text {dobq }}\right), 100.09$ (4C, C Otf $), 97.03$ (4C, C cym), $92.11\left(4 \mathrm{C}, \mathrm{C}_{\mathrm{C} \equiv \mathrm{C}}\right), 90.63\left(4 \mathrm{C}, \mathrm{C}_{\mathrm{C} \equiv \mathrm{C}}\right), 84.60\left(8 \mathrm{C}, \mathrm{C}_{\mathrm{cym}}\right), 82.62\left(8 \mathrm{C}, \mathrm{C}_{\text {cym }}\right), 32.12\left(4 \mathrm{C}, \mathrm{C}_{\text {cym }}\right), 22.48(8 \mathrm{C}$, $\left.\mathrm{C}_{\mathrm{cym}}\right), 18.24\left(4 \mathrm{C}, \mathrm{C}_{\mathrm{cym}}\right)$. IR ( $\left.\mathrm{cm}^{-1}\right): 3075$ (w; C-H aromatic), 2198 (w; C $\left.\equiv \mathrm{C}\right), 1574$ (m; C=C aromatic),

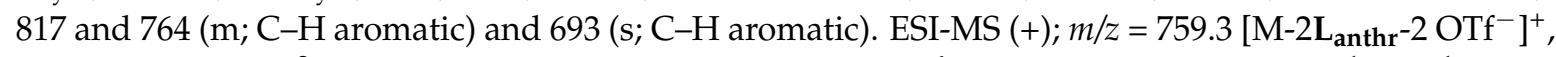
$1139.2\left[\mathrm{M}-2 \mathrm{OTf}^{-}\right]^{2+}, 2423.0\left[\mathrm{M}-\mathrm{OTf}^{-}\right]^{+}$. UV-vis $\left[5.0 \times 10^{-6}, \mathrm{CH}_{2} \mathrm{Cl}_{2} ; \lambda_{\max }, \mathrm{nm}\left(\varepsilon, \mathrm{M}^{-1} \cdot \mathrm{cm}^{-1}\right)\right]: 274$ $\left(1.2 \times 10^{5}\right), 314\left(8.3 \times 10^{4}\right), 457\left(8.2 \times 10^{4}\right), 722\left(8.2 \times 10^{3}\right) . \mathrm{D}\left(\left(\mathrm{CD}_{3}\right)_{2} \mathrm{CO}\right): 6.04 \times 10^{-10} \mathrm{~m}^{2} \cdot \mathrm{s}^{-1}$. Anal. calc. for $\mathrm{C}_{112} \mathrm{H}_{92} \mathrm{~F}_{12} \mathrm{~N}_{4} \mathrm{O}_{20} \mathrm{Ru}_{4} \mathrm{~S}_{4}$ (2572.46): C 52.24, H 3.61, N 2.18; Found: C 52.45, H 3.81, N 2.22.

$\left[\mathrm{Ru}_{4}\left(\eta^{6}-p \text {-cymene }\right)_{4}\left(\mu_{4} \text {-donq) }\right)_{2}\left(\mu_{2}-\mathrm{L}_{\mathrm{anthr}}\right)_{2}\right]\left[\mathrm{CF}_{3} \mathrm{SO}_{3}\right]_{4}\left(\mathrm{~A}_{3}\right):$ Green solid. Yield, 82\%. NMR $\left(\left(\mathrm{CD}_{3}\right)_{2} \mathrm{CO}, 400 \mathrm{MHz}\right): \delta 8.72\left(\mathrm{~s}, 4 \mathrm{H}, \mathrm{CH}_{\mathrm{pyr}}\right), 8.55\left(\mathrm{~d}, J=6.8 \mathrm{~Hz}, 4 \mathrm{H}, \mathrm{CH}_{\text {pyr }}\right), 8.48(\mathrm{~d}, J=5.6 \mathrm{~Hz}$, $\left.4 \mathrm{H}, \mathrm{CH}_{\text {pyr }}\right), 8.01\left(\mathrm{dd}, J=6.4 \mathrm{~Hz}, J=2.8 \mathrm{~Hz}, 8 \mathrm{H}, \mathrm{CH}_{\text {anthr }}\right), 7.62\left(\mathrm{t}, J=6.8 \mathrm{~Hz}, 4 \mathrm{H}, \mathrm{CH}_{\mathrm{pyr}}\right), 7.48(\mathrm{dd}, J=6.8$ $\left.\mathrm{Hz}, J=3.2 \mathrm{~Hz}, 8 \mathrm{H}, \mathrm{CH}_{\text {anthr }}\right), 7.44\left(\mathrm{~s}, 8 \mathrm{H}, \mathrm{CH}_{\mathrm{donq}}\right), 6.09\left(\mathrm{~d}, J=6.0 \mathrm{~Hz}, 8 \mathrm{H}, \mathrm{CH}_{\mathrm{cym}}\right), 5.86(\mathrm{~d}, J=6.0 \mathrm{~Hz}$, $8 \mathrm{H}, \mathrm{CH}_{\text {cym }}$ ), 3.04 (sept, $J=6.8 \mathrm{~Hz}, 4 \mathrm{H}, \mathrm{CH}_{\text {cym }}$ ), 2.26 (s, 12H, $\mathrm{CH}_{3 \text { cym }}$ ), 1.42 (d, J = 6.8 Hz, 24H, $\mathrm{CH}_{\text {cym }}$ ). 
${ }^{13} \mathrm{C}$ NMR ((CD $\left.)_{2} \mathrm{CO}, 400 \mathrm{MHz}\right): \delta 154.93$ (4C, $\left.\mathrm{C}_{\text {pyr }}\right), 152.73$ (4C, $\left.\mathrm{C}_{\text {pyr }}\right), 142.40\left(4 \mathrm{C}, \mathrm{C}_{\text {pyr }}\right), 138.58(8 \mathrm{C}$, $\left.\mathrm{C}_{\text {donq }}\right), 132.98$ (4C, $\left.\mathrm{C}_{\text {donq }}\right), 131.79$ (8C, $\left.\mathrm{C}_{\text {anthr }}\right), 128.31$ (8C, $\left.\mathrm{C}_{\text {anthr }}\right), 127.03$ (8C, $\left.\mathrm{C}_{\text {anthr }}\right), 126.82$ (4C, $\left.\mathrm{C}_{\text {pyr }}\right)$, 122.85 (4C, $\left.\mathrm{C}_{\text {pyr }}\right), 117.66$ (4C, $\left.\mathrm{C}_{\text {anthr }}\right), 112.43$ (8C, $\left.\mathrm{C}_{\text {donq }}\right), 109.28$ (4C, $\left.\mathrm{C}_{\mathrm{Otf}}\right), 104.41$ (4C, $\left.\mathrm{C}_{\text {cym }}\right), 100.94$ (4C, $\left.\mathrm{C}_{\mathrm{cym}}\right), 97.22\left(4 \mathrm{C}, \mathrm{C}_{\mathrm{C} \equiv \mathrm{C}}\right), 91.66\left(4 \mathrm{C}, \mathrm{C}_{\mathrm{C} \equiv \mathrm{C}}\right), 85.47\left(8 \mathrm{C}, \mathrm{C}_{\mathrm{cym}}\right), 83.72\left(8 \mathrm{C}, \mathrm{C}_{\mathrm{cym}}\right), 31.62\left(4 \mathrm{C}, \mathrm{C}_{\mathrm{cym}}\right), 22.48(8 \mathrm{C}$, $\left.\mathrm{C}_{\mathrm{cym}}\right), 17.43$ (4C, $\mathrm{C}_{\mathrm{cym}}$ ). IR ( $\left.\mathrm{cm}^{-1}\right): 2971$ (w; C-H aromatic), 2204 (w; $\left.\mathrm{C} \equiv \mathrm{C}\right), 1531$ (m; C=C aromatic), 967, 852 and 763 (m; C-H aromatic), 635 (s, sharp; C-H aromatic). ESI-MS (+); $m / z=809.0$ [M-2 $\mathbf{L}_{\text {anthr }}-2$ $\left.\mathrm{OTf}^{-}\right]^{+}, 1188.1\left[\mathrm{M}-2 \mathrm{OTf}^{-}\right]^{2+}$. UV-vis $\left[5.0 \times 10^{-6}, \mathrm{CH}_{2} \mathrm{Cl}_{2} ; \lambda_{\max }, \mathrm{nm}\left(\varepsilon, \mathrm{M}^{-1} \cdot \mathrm{cm}^{-1}\right)\right]: 271\left(1.8 \times 10^{5}\right)$, $310\left(9.0 \times 10^{4}\right), 445\left(9.1 \times 10^{4}\right), 476\left(6.7 \times 10^{4}\right), 694\left(1.9 \times 10^{4}\right) . \mathrm{D}\left(\left(\mathrm{CD}_{3}\right)_{2} \mathrm{CO}\right): 6.80 \times 10^{-10} \mathrm{~m}^{2} \cdot \mathrm{s}^{-1}$.

X-ray crystallography: Crystals were mounted on a Stoe Image Plate Diffraction system equipped with a $\Phi$ circle goniometer, using Mo K $\alpha$ graphite monochromated radiation $(\lambda=0.71073 \AA)$ with $\Phi$ range $0-200^{\circ}$. The structures were solved by direct methods using the program SHELXS-97 [83], while the refinement and all further calculations were carried out using SHELXL-97. The H-atoms were included in calculated positions and treated as riding atoms using SHELXL-97 default parameters. The non-H atoms were refined anisotropically using weighted full-matrix least-square on $F^{2}$. In both structures, relatively high $R$ factors are observed due to disorder within the crystals. Crystallographic details are summarized in Table 2, and Figures 2 and 4 were drawn with ORTEP-32 [84].

Table 2. Crystallographic data and structure refinement parameters for $\mathbf{L}_{\mathbf{a n t h r}}$ and $\mathbf{A}_{\mathbf{1}} \cdot 4$ acetone.

\begin{tabular}{|c|c|c|}
\hline Parameters & $\mathbf{L}_{\text {anthr }}$ & $A_{1} \cdot 4$ acetone \\
\hline chemical formula & $\mathrm{C}_{28} \mathrm{H}_{16} \mathrm{~N}_{2}$ & $\mathrm{C}_{116} \mathrm{H}_{112} \mathrm{~F}_{12} \mathrm{~N}_{4} \mathrm{O}_{24} \mathrm{Ru}_{4} \mathrm{~S}_{4}$ \\
\hline formula weight & 380.43 & 2706.61 \\
\hline crystal system & monoclinic & triclinic \\
\hline space group & $P 2_{1}$ & $P-1$ \\
\hline crystal size $\left(\mathrm{mm}^{3}\right)$ & $0.23 \times 0.13 \times 0.12$ & $0.25 \times 0.18 \times 0.14$ \\
\hline crystal color and shape & colorless rod & yellow plate \\
\hline$a(\AA)$ & $5.0015(6)$ & $16.0557(11)$ \\
\hline$b(\AA)$ & $16.944(2)$ & 20.7694(15) \\
\hline$c(\AA)$ & $11.5374(15)$ & $21.3136(14)$ \\
\hline$\alpha\left(^{\circ}\right)$ & 90 & $115.639(5)$ \\
\hline$\beta\left(^{\circ}\right)$ & $92.433(10)$ & $98.267(5)$ \\
\hline$\gamma\left({ }^{\circ}\right)$ & 90 & $101.194(6)$ \\
\hline cell volume $\left(\AA^{3}\right)$ & $976.9(2)$ & $6073.6(8)$ \\
\hline$T(\mathrm{~K})$ & 293(2) & 203(2) \\
\hline Z & 2 & 2 \\
\hline scan range $\left({ }^{\circ}\right)$ & $1.77<\theta<29.30$ & $1.48<\theta<29.33$ \\
\hline$\rho_{\text {calcd }}\left(\mathrm{g} \mathrm{cm}^{-3}\right)$ & 1.293 & 1.480 \\
\hline$\mu\left(\mathrm{mm}^{-1}\right)$ & 0.076 & 0.644 \\
\hline unique reflections & 5272 & 32944 \\
\hline reflections used $[I>2 \sigma(I)]$ & 1378 & 9666 \\
\hline$R_{\text {int }}$ & 0.1715 & 0.2498 \\
\hline final $R$ indices $\left[I>2 \sigma(I){ }^{[a]}\right.$ & $0.0799, w R_{2} 0.1714$ & $0.0911, w R_{2} 0.2228$ \\
\hline$R$ indices (all data) ${ }^{[b]}$ & $0.2499, w R_{2} 0.2388$ & $0.2609, w R_{2} 0.2939$ \\
\hline $\mathrm{GOF}^{[\mathrm{c}]}$ & 0.805 & 0.836 \\
\hline $\max , \min \Delta \rho / e\left(\AA^{-3}\right)$ & $0.268,-0.196$ & $1.627,-1.213$ \\
\hline
\end{tabular}

CCDC-1853676 ( $\left.\mathbf{L}_{\text {anthr }}\right)$ and $1853677\left(\mathbf{A}_{\mathbf{1}} \cdot 4\right.$ acetone) contain the supplementary crystallographic data for this paper. This can be obtained free of charge at www.ccdc.cam.ac.uk/conts/retrieving.html (or from the Cambridge Crystallographic Data Center, 12, Union Road, Cambridge CB2 1EZ, UK; fax: (internat.) +44-1223/336-033; E-mail: deposit@ccdc.cam.ac.uk). 


\section{Conclusions}

Three metalla-rectangles containing anthracene-derived linkers have been synthesized and characterized. Upon formation of the metalla-assembly, the propensity of the anthracene moiety to react with oxygen to form endoperoxide derivatives was lost, probably due to electronic or steric constraints. Nevertheless, the introduction of anthracene groups on metalla-assemblies remains an interesting avenue to transport oxygen to cancer cells; however, in view of this study, the anthracene moiety should be anchored elsewhere to allow the formation of metalla-assemblies with endoperoxide groups.

Supplementary Materials: All NMR and mass spectra are available online at http:/ / www.mdpi.com/2304-6740/ 6/3/97/s1. Cif and Check cif files of $\mathrm{C}_{28} \mathrm{H}_{16} \mathrm{~N}_{2}$ ( $\mathbf{L}_{\text {anthr }}$ ) and $\mathrm{C}_{116} \mathrm{H}_{112} \mathrm{~F}_{12} \mathrm{~N}_{4} \mathrm{O}_{24} \mathrm{Ru}_{4} \mathrm{~S}_{4}\left(\mathbf{A}_{1} \cdot 4\right.$ acetone).

Author Contributions: For research articles with several authors, a short paragraph specifying their individual contributions must be provided. The following statements should be used "conceptualization, B.T.; methodology, M.G., F.N. and T.C.; validation, M.G., F.N., T.C. and B.T.; formal analysis, M.G., T.C. and F.N.; investigation, M.G., T.C. and F.N.; writing - original draft preparation, M.G. and B.T.; writing-review and editing, M.G. and B.T.; supervision, B.T.; project administration, B.T.", please turn to the CRediT taxonomy for the term explanation. Authorship must be limited to those who have contributed substantially to the work reported.

Funding: This research was funded by the University of Neuchatel, Switzerland.

Acknowledgments: Marie Gaschard thanks the University of Neuchâtel for financial support.

Conflicts of Interest: The authors declare no conflict of interest.

\section{References}

1. Zuluaga, M.F.; Lange, N. Combination of photodynamic therapy with anti-cancer agents. Curr. Med. Chem. 2008, 15, 1655-1673. [CrossRef] [PubMed]

2. Dolmans, D.E.J.G.J.; Fukumura, D.; Jain, R.K. Photodynamic therapy for cancer. Nat. Rev. Cancer 2003, 3, 380-387. [CrossRef] [PubMed]

3. Usuda, J.; Kato, H.; Okunaka, T.; Furukawa, K.; Tsutsui, H.; Yamada, K.; Suga, Y.; Honda, H.; Nagatsuka, Y.; Ohira, T.; et al. Photodynamic therapy (PDT) for lung cancers. J. Thorac. Oncol. 2006, 1, 489-493. [CrossRef]

4. Baron, E.D.; Malbasa, C.L.; Santo-Domingo, D.; Fu, P.; Miller, J.D.; Hanneman, K.K.; Hsia, A.H.; Oleinick, N.L.; Colussi, V.C.; Cooper, K.D. Silicon phthalocyanine (Pc4) photodynamic therapy is a safe modality for cutaneous neoplasms: Results of a phase 1 clinical trial. Lasers Surg. Med. 2010, 42, 728-735. [CrossRef] [PubMed]

5. Babilas, P.; Schreml, S.; Landthaler, M.; Szeimies, R.M. Photodynamic therapy in dermatology: State-of-the-art. Photodermatol. Photoimmunol. Photomed. 2010, 26, 118-132. [CrossRef] [PubMed]

6. Kharkwal, G.B.; Sharma, S.K.; Huang, Y.Y.; Dai, T.; Hamblin, M.R. Photodynamic therapy for infections: Clinical applications. Lasers Surg. Med. 2011, 43, 755-767. [CrossRef] [PubMed]

7. Hamblin, M.R.; Hasan, T. Photodynamic therapy: A new antimicrobial approach to infectious disease? Photochem. Photobiol. Sci. 2004, 3, 436-450. [CrossRef] [PubMed]

8. Dunn, J.M.; Mackenzie, G.D.; Banks, M.R.; Mosse, C.A.; Haidry, R.; Green, S.; Thorpe, S.; Rodriguez-Justo, M.; Winstanley, A.; Novelli, M.R.; et al. A randomised controlled trial of ALA vs. Photofrin photodynamic therapy for high-grade dysplasia arising in Barrett's oesophagus. Lasers Med. Sci. 2013, 28, 707-715. [CrossRef] [PubMed]

9. Schweitzer, V.G.; Somers, M.L. PHOTOFRIN-mediated photodynamic therapy for treatment of early stage (Tis-T2N0M0) SqCCa of oral cavity and oropharynx. Lasers Surg. Med. 2010, 42, 1-8. [CrossRef] [PubMed]

10. Yu, J.; Hsu, C.H.; Huang, C.C.; Chang, P.Y. Development of therapeutic Au-methylene blue nanoparticles for targeted photodynamic therapy of cervical cancer cells. ACS Appl. Mater. Interfaces 2015, 7, 432-441. [CrossRef] [PubMed]

11. Yavari, N.; Andersson-Engels, S.; Segersten, U.; Malmstrom, P.U. An overview on preclinical and clinical experiences with photodynamic therapy for bladder cancer. Can. J. Urol. 2011, 18, 5343-5351.

12. Montazerabadi, A.R.; Sazgarnia, A.; Bahreyni-Toosi, M.H.; Ahmadi, A.; Aledavood, A. The effects of combined treatment with ionizing radiation and indocyanine green-mediated photodynamic therapy on breast cancer cells. J. Photochem. Photobiol. B 2012, 109, 42-49. [CrossRef] [PubMed] 
13. Wakui, M.; Yokoyama, Y.; Wang, H.; Shigeto, T.; Futagami, M.; Mizunuma, H. Efficacy of a methyl ester of 5-aminolevulinic acid in photodynamic therapy for ovarian cancers. J. Cancer Res. Clin. Oncol. 2010, 136, 1143-1150. [CrossRef] [PubMed]

14. Agostinis, P.; Berg, K.; Cengel, K.A.; Foster, T.H.; Girotti, A.W.; Gollnick, S.O.; Hahn, S.M.; Hamblin, M.R.; Juzeniene, A.; Kessel, D.; et al. Photodynamic therapy of cancer: An update. CA Cancer J. Clin. 2011, 61, 250-281. [CrossRef] [PubMed]

15. Patrice, T.; Moor, A.C.E.; Ortel, B.; Hasan, T. Mechanism of photodynamic therapy. In Photodynamic Therapy; Patrice, T., Ed.; The Royal Society of Chemistry: Cambridge, UK, 2003; Volume 2, pp. 19-58.

16. Castano, A.P.; Demidova, T.N.; Hamblin, M.R. Mechanisms in photodynamic therapy: Part three-Photosensitizer pharmacokinetics, biodistribution, tumor localization and modes of tumor destruction. Photodiagn. Photodyn. Ther. 2005, 2, 91-106. [CrossRef]

17. Foote, C.S. Definition of type I and type II photosensitized oxidation. Photochem. Photobiol. 1991, 54, 659. [CrossRef] [PubMed]

18. Debele, T.A.; Peng, S.; Tsai, H.C. Drug carrier for photodynamic cancer therapy. Int. J. Mol. Sci. 2015, 16, 22094-22136. [CrossRef] [PubMed]

19. Allison, R.R.; Moghissi, K. Photodynamic Therapy (PDT): PDT Mechanisms. Clin. Endosc. 2013, 46, $24-29$. [CrossRef] [PubMed]

20. Brown, J.M.; Wilson, W.R. Exploiting tumour hypoxia in cancer treatment. Nat. Rev. Cancer 2004, 4, 437-447. [CrossRef] [PubMed]

21. Gray, L.H.; Conger, A.D.; Ebert, M.; Hornsey, S.; Scott, O.C. The concentration of oxygen dissolved in tissues at the time of irradiation as a factor in radiotherapy. Br. J. Radiol. 1953, 26, 638-648. [CrossRef] [PubMed]

22. Thomlinson, R.H.; Gray, L.H. The histological structure of some human lung cancers and the possible implications for radiotherapy. Br. J. Radiol. 1955, 9, 539-549. [CrossRef]

23. Vaupel, P.; Schlenger, K.; Knoop, C.; Höckel, M. Oxygenation of human tumors: Evaluation of tissue oxygen distribution in breast cancers by computerized $\mathrm{O}_{2}$ tension measurements. Cancer Res. 1991, 51, 3316-3322. [PubMed]

24. Nordsmark, M.; Overgaard, M.; Overgaard, J. Pretreatment oxygenation predicts radiation response in advanced squamous cell carcinoma of the head and neck. Radiother. Oncol. 1996, 41, 31-39. [CrossRef]

25. Brizel, D.M.; Dodge, R.K.; Clough, R.W.; Dewhirst, M.W. Oxygenation of head and neck cancer: Changes during radiotherapy and impact on treatment outcome. Radiother. Oncol. 1999, 53, 113-117. [CrossRef]

26. Durand, R.E. Keynote address: The influence of microenvironmental factors on the activity of radiation and drugs. Int. J. Radiat. Oncol. Biol. Phys. 1991, 20, 253-258. [CrossRef]

27. Batchelder, R.M.; Wilson, W.R.; Hay, M.P.; Denny, W.A. Oxygen dependence of the cytotoxicity of the enediyne anti-tumour antibiotic esperamicin A1. Br. J. Cancer Suppl. 1996, 27, S52-S56. [PubMed]

28. Teicher, B.A.; Lazo, J.S.; Sartorelli, A.C. Classification of antineoplastic agents by their selective classification of antineoplastic agents by their selective toxicities toward oxygenated and hypoxic tumor cells. Cancer Res. 1981, 41, 73-81. [PubMed]

29. Mizukami, Y.; Li, J.; Zhang, X.; Zimmer, M.A.; Iliopoulos, O.; Chung, D.C. Hypoxia-inducible factor-1-independent regulation of vascular endothelial growth factor by hypoxia in colon cancer. Cancer Res. 2004, 64, 1765-1772. [CrossRef] [PubMed]

30. Wartenberg, M.; Ling, F.C.; Müschen, M.; Klein, F.; Acker, H.; Gassmann, M.; Petrat, K.; Pütz, V.; Hescheler, J.; Sauer, H. Regulation of the multidrug resistance transporter P-glycoprotein in multicellular tumor spheroids by hypoxia-inducible factor (HIF-1) and reactive oxygen species. FASEB J. 2003, 17, 503-505. [CrossRef] [PubMed]

31. Graeber, T.G.; Osmanian, C.; Jacks, T.; Housman, D.E.; Koch, C.J.; Lowe, S.W.; Giaccia, A.J. Hypoxia-mediated selection of cells with diminished apoptotic potential in solid tumours. Nature 1996, 379, 88-91. [CrossRef] [PubMed]

32. Erler, J.T.; Cawthorne, C.W.; Williams, K.J.; Koritzinsky, M.; Wouters, B.G.; Wilson, C.; Miler, C.; Demonacos, C.; Stratford, I.J.; Dive, C. Hypoxia-mediated down-regulation of Bid and Bax in tumors occurs via hypoxia-inducible factor 1-dependent and -independent mechanisms and contributes to drug resistance. Mol. Cell. Biol. 2004, 24, 2875-2889. [CrossRef] [PubMed]

33. Yuan, J.; Glazer, P.M. Mutagenesis induced by the tumor microenvironment. Mutat. Res. Fundam. Mol. Mech. Mutagen. 1998, 400, 439-446. [CrossRef] 
34. Harris, A.L. Hypoxia-a key regulatory factor in tumour growth. Nat. Rev. Cancer 2002, 2, 38-47. [CrossRef] [PubMed]

35. Rouschop, K.M.A.; van den Beucken, T.; Dubois, L.; Niessen, H.; Bussink, J.; Savelkouls, K.; Keulers, T.; Mujcic, H.; Landuyt, W.; Voncken, J.W.; et al. The unfolded protein response protects human tumor cells during hypoxia through regulation of the autophagy genes MAP1LC3B and ATG5. J. Clin. Investing. 2010, 120, 127-141. [CrossRef] [PubMed]

36. Wang, Y.; Ohh, M. Oxygen-mediated endocytosis in cancer. J. Cell. Mol. Med. 2010, 14, 496-503. [CrossRef] [PubMed]

37. Semenza, G.L. Hypoxia, clonal selection, and the role of HIF-1 in tumor progression. Crit. Rev. Biochem. Mol. Biol. 2000, 35, 71-103. [CrossRef] [PubMed]

38. Kioi, M.; Vogel, H.; Schultz, G.; Hoffman, R.M.; Harsh, G.R.; Brown, J.M. Inhibition of vasculogenesis, but not angiogenesis, prevents the recurrence of glioblastoma after irradiation in mice. J. Clin. Investing. 2010, 120, 694-705. [CrossRef] [PubMed]

39. Therrien, B. Transporting and shielding photosensitizers by using water-soluble organometallic cages: A new strategy in drug delivery and photodynamic therapy. Chem. Eur. J. 2013, 19, 8378-8386. [CrossRef] [PubMed]

40. Mari, C.; Pierroz, V.; Ferrari, S.; Gasser, G. Combination of Ru(II) complexes and light: New frontiers in cancer therapy. Chem. Sci. 2015, 6, 2660-2686. [CrossRef] [PubMed]

41. Huang, H.; Bole, Y.; Zhang, P.; Huang, J.; Chen, Y.; Gasser, G.; Ji, L.; Chao, H. Highly charged ruthenium(II) polypyridyl complexes as lysosome-localized photosensitizers for two-photon photodynamic therapy. Angew. Chem. Int. Ed. 2015, 54, 14049-14052. [CrossRef] [PubMed]

42. Pierroz, V.; Rubbiani, R.; Gentili, C.; Patra, M.; Mari, C.; Gasser, G.; Ferrari, S. Dual mode of cell death upon the photo-irradiation if a Ru(II) polypyridyl complex in interphase or mitosis. Chem. Sci. 2016, 7, 6115-6124. [CrossRef] [PubMed]

43. Hess, J.; Huang, H.; Kaiser, A.; Pierroz, V.; Blacque, O.; Chao, H.; Gasser, G. Evaluation of the medicinal potential of two ruthenium(II) polypyridine complexes as one- and two-photon photodynamic therapy photosensitizers. Chem. Eur. J. 2017, 23, 9888-9896. [CrossRef] [PubMed]

44. Heinemann, F.; Karges, J.; Gasser, G. Critical overview of the use of Ru(II) polypyridyl complexes as photosensitizers in one-photon and two-photon photodynamic therapy. Acc. Chem. Res. 2017, 50, 2727-2736. [CrossRef] [PubMed]

45. Liu, J.; Zhang, C.; Rees, T.W.; Ke, L.; Ji, L.; Chao, H. Harnessing ruthenium(II) as photodynamic agents: Encouraging advances in cancer therapy. Coord. Chem. Rev. 2018, 363, 17-28. [CrossRef]

46. Alessio, E.; Mestroni, G.; Bergamo, A.; Sava, G. Ruthenium antimetastatic agents. Curr. Top. Med. Chem. 2004, 4, 1525-1535. [CrossRef] [PubMed]

47. Ang, W.H.; Dyson, P.J. Classical and non-classical ruthenium-based anticancer drugs: Towards targeted chemotherapy. Eur. J. Inorg. Chem. 2006, 2006, 4003-4018. [CrossRef]

48. Bergamo, A.; Sava, G. Ruthenium complexes can target determinants of tumors malignancy. Dalton Trans. 2007, 13, 1267-1272. [CrossRef] [PubMed]

49. Hartinger, C.G.; Dyson, P.J. Bioorganometallic chemistry-From teaching paradigms to medicinal applications. Chem. Soc. Rev. 2009, 38, 391-401. [CrossRef] [PubMed]

50. Bruijnincx, P.C.A.; Sadler, P.J. New trends for metal complexes with anticancer activity. Curr. Opin. Chem. Biol. 2008, 12, 197-206. [CrossRef] [PubMed]

51. Meggers, E.; Atilla-Gokcumen, G.E.; Bregman, H.; Maksimoska, J.; Mulcahy, S.P.; Pagano, N.; Williams, D.S. Exploring chemical space with organometallics: Ruthenium complexes as protein kinase inhibitors. Synlett 2007, 8, 1177-1189. [CrossRef]

52. Boca, S.C.; Four, M.; Bonn, A.; van der Sanden, B.; Astilean, S.; Baldec, P.L.; Lemercier, G. An ethylene-glycol decorated ruthenium(II) complex for two-photon photodynamic therapy. Chem. Commun. 2009, 0, 4590-4592. [CrossRef] [PubMed]

53. Schmidt, R. Photosensitized generation of singlet oxygen. Photochem. Photobiol. 2006, 82, 1161-1177. [CrossRef] [PubMed]

54. Schmitt, F.; Govindaswamy, P.; Süss-Fink, G.; Ang, W.H.; Dyson, P.J.; Juillerat-Jeanneret, L.; Therrien, B. Ruthenium porphyrin compounds for photodynamic therapy of cancer. J. Med. Chem. 2008, 51, 1811-1816. [CrossRef] [PubMed] 
55. Pernot, M.; Bastogne, T.; Barry, N.P.E.; Therrien, B.; Koellensperger, G.; Hann, S.; Reshetov, V.; Barberi-Heyob, M. Systems biology approach for in vivo photodynamic therapy optimization of ruthenium-porphyrin compounds. J. Photochem. Photobiol. B 2012, 117, 80-89. [CrossRef] [PubMed]

56. Schmitt, F.; Govindaswamy, P.; Zava, O.; Süss-Fink, G.; Juillerat-Jeanneret, L.; Therrien, B. Combined arene ruthenium porphyrins as chemotherapeutics and photosensitizers for cancer therapy. J. Biol. Inorg. Chem. 2009, 14, 101-109. [CrossRef] [PubMed]

57. Freudenreich, J.; Barry, N.P.E.; Süss-Fink, G.; Therrien, B. Permanent encapsulation or host-guest behavior of aromatic molecules in hexanuclear arene ruthenium prisms. Eur. J. Inorg. Chem. 2010, 2010, 2400-2405. [CrossRef]

58. Freudenreich, J.; Furrer, J.; Süss-Fink, G.; Therrien, B. Template-directed synthesis of hexanuclear arene ruthenium complexes with trigonal-prismatic architecture based on 2,4,6-tris(3-pyridyl)triazine ligands. Organometallics 2011, 30, 942-951. [CrossRef]

59. Freudenreich, J.; Dalvit, C.; Süss-Fink, G.; Therrien, B. Encapsulation of photosensitizers in hexa- and octanuclear organometallic cages: Synthesis and characterization of carceplex and host-guest systems in solution. Organometallics 2013, 32, 3018-3033. [CrossRef]

60. Schmitt, F.; Freudenreich, J.; Barry, N.P.E.; Juillerat-Jeanneret, L.; Süss-Fink, G.; Therrien, B. Organometallic cages as vehicles for intracellular release of photosensitizers. J. Am. Chem. Soc. 2012, 134, 754-757. [CrossRef] [PubMed]

61. Cobo, S.; Lafolet, F.; Saint-Aman, E.; Philouze, C.; Bucher, C.; Silvi, S.; Credi, A.; Royal, G. Reactivity of a pyridinium-substituted dimethyldihydropyrene switch under aerobic conditions: Self-sensitized photo-oxygenation and thermal release of singlet oxygen. Chem. Comm. 2015, 51, 13886-13889. [CrossRef] [PubMed]

62. Benz, S.; Nötzli, S.; Siegel, J.S.; Eberli, D.; Jessen, H.J. Controlled oxygen release from pyridone endoperoxides promotes cell survival under anoxic conditions. J. Med. Chem. 2013, 56, 10171-10182. [CrossRef] [PubMed]

63. Klaper, M.; Linker, T. Evidence for an oxygen anthracene sandwich complex. Angew. Chem. Int. Ed. 2013, 52, 11896-11899. [CrossRef] [PubMed]

64. Liu, H.W.; Xu, S.; Wang, P.; Hu, X.X.; Zhang, J.; Yuan, L.; Zhang, X.B.; Tan, W. An efficient two-photon fluorescent probe for monitoring mitochondrial singlet oxygen in tissues during photodynamic therapy. Chem. Commun. 2016, 52, 12330-12333. [CrossRef] [PubMed]

65. Asadirad, A.M.; Erno, Z.; Branda, N.R. Photothermal release of singlet oxygen from gold nanoparticles. Chem. Commun. 2013, 49, 5639-5641. [CrossRef] [PubMed]

66. Aubry, J.M.; Pierlot, C.; Rigaudy, J.; Schmidt, R. Reversible binding of oxygen to aromatic compounds. Acc. Chem. Res. 2003, 36, 668-675. [CrossRef] [PubMed]

67. Ciesielski, A.; Piot, L.; Samorì, P.; Jouaiti, A.; Hosseini, M.W. Molecular tectonics at the solid/liquid interface: Controlling of 1D coordination networks on graphite surfaces. Adv. Mater. 2009, 21, 1131-1136. [CrossRef]

68. Yan, H.; Süss-Fink, G.; Neels, A.; Stoeckli-Evans, H. Mono-, di- and tetra-nuclear $p$-cymene ruthenium complexes containing oxalato ligands. J. Chem. Soc. Dalton Trans. 1997, 1997, 4345-4350. [CrossRef]

69. Therrien, B.; Süss-Fink, G.; Govindaswamy, P.; Renfrew, A.K.; Dyson, P.J. The "complex-in-a-complex" cations $\left[(\mathrm{acac})_{2} \mathrm{M} \subset \mathrm{Ru} 6\left(p-i \mathrm{PrC}_{6} \mathrm{H}_{4} \mathrm{Me}\right)_{6}(\mathrm{tpt})_{2}(\mathrm{dhbq})_{3}\right]^{6+}:$ A trojan horse for cancer cells. Angew. Chem. Int. Ed. Engl. 2008, 47, 3773-3776. [CrossRef] [PubMed]

70. Barry, N.P.E.; Therrien, B. Host-Guest Chemistry in the Hexanuclear (Arene)ruthenium Metalla-Prismatic Cage $\left[\mathrm{Ru}_{6}(p \text {-cymene })_{6}(\mathrm{tpt})_{2}(\mathrm{dhnq})_{3}\right]^{6+}$. Eur. J. Inorg. Chem. 2009, 2009, 4695-4700. [CrossRef]

71. Therrien, B. Arene Ruthenium Cages: Boxes Full of Surprises. Eur. J. Inorg. Chem. 2009, 2009, $2445-2453$. [CrossRef]

72. Barry, N.; Furrer, J.; Therrien, B. In- and Out-of-Cavity Interactions by Modulating the Size of Ruthenium Metallarectangles. Helv. Chim. Acta 2010, 93, 1313-1328. [CrossRef]

73. Johnson, C.S., Jr. Diffusion ordered nuclear magnetic resonance spectroscopy: Principles and applications. Prog. Nucl. Magn. Reson. Spectrosc. 1999, 34, 203-256. [CrossRef]

74. Barry, N.P.E.; Furrer, J.; Freudenreich, J.; Süss-Fink, G.; Therrien, B. Designing the host-guest properties of tetranuclear arene ruthenium metalla-rectangles to accommodate a pyrene molecule. Eur. J. Inorg. Chem. 2010, 5, 725-728. [CrossRef] 
75. Tidmarsh, I.S.; Taylor, B.F.; Hardie, M.J.; Russo, L.; Clegg, W.; Ward, M.D. Further investigations into tetrahedral $\mathrm{M}_{4} \mathrm{~L}_{6}$ cage complexes containing guest anions: New structures and NMR spectroscopic studies. New J. Chem. 2009, 33, 366-375. [CrossRef]

76. Furrer, M.A.; Schmitt, F.; Wiederkehr, M.; Juillerat-Jeanneret, L.; Therrien, B. Cellular delivery of pyrenyl-arene ruthenium complexes by a water-soluble arene ruthenium metalla-cage. Dalton Trans. 2012, 41, 7201-7211. [CrossRef] [PubMed]

77. Lee, H.; Elumalai, P.; Singh, N.; Kim, H.; Lee, S.U.; Chi, K.W. Selective synthesis of ruthenium(II) metalla[2]-catenane via solvent and guest-dependent self-assembly. J. Am. Chem. Soc. 2015, 137, 4674-4677. [CrossRef] [PubMed]

78. Díaz-Uribe, C.E.; Vallejo-Lozada, W.A.; Martínez-Ortega, F. Photooxidation of anthracene under visible light with metallocarboxyphenylporphyrins. Rev. Fac. Ing. Univ. Antioquia 2014, 73, 225-230.

79. Alvariño Bouza, C. Autoensamblaje de nuevos metalociclos, complejos de inclusión y moléculas mecánicamenta entrelazadas. Ph.D. Thesis, Universidade da Coruña, A Coruña, Spain, 2015.

80. Ware, W.R. Oxygen quenching of fluorescence in solution: An experimental study of the diffusion process. J. Phys. Chem. 1962, 66, 455-458. [CrossRef]

81. Berlman, I.B.; Steingraber, O.J. Further evidence of a hidden singlet transition in biphenyl. J. Chem. Phys. 1965, 43, 2140-2141. [CrossRef]

82. Lemp, E.; Zanocco, A.L. Singlet oxygen chemical acceptors. In Singlet Oxygen: Applications in Biosciences and Nanosciences; Nonell, S., Flors, C., Eds.; The Royal Society of Chemistry: Cambridge, UK, 2016; Volume 2, pp. 83-101.

83. Sheldrick, G.M. A short history of SHELX. Acta Crystallogr A 2008, 64, 112-122. [CrossRef] [PubMed]

84. Farrugia, L.J. ORTEP-3 for Windows-A version of ORTEP-III with a Graphical User Interface (GUI). J. Appl. Cryst. 1997, 30, 565. [CrossRef]

(C) 2018 by the authors. Licensee MDPI, Basel, Switzerland. This article is an open access article distributed under the terms and conditions of the Creative Commons Attribution (CC BY) license (http://creativecommons.org/licenses/by/4.0/). 